\title{
VITREOUS CHINA PLUMBING FIXTURES
}

(Fifth Edition)

\section{COMMERCIAL STANDARD CS20-49}

(Supersedes CS20-47)

Effective Date for New Production From December 15, 1949

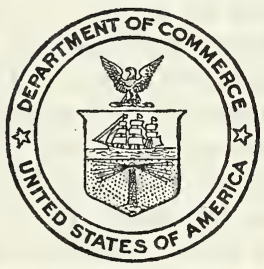

A RECORDED VOLUNTARY STANDARD

OF THE TRADE

UNITED STATES DEPARTMENT OF COMMERCE

CHARLES SAWYER, Secretary

For sale by the Superintendent of Documents, U. S. Government Printing Office Washington 25, D. C. - Price 15 cents 


\section{COMMODITY STANDARDS}

Simplified Practice Recommendations and Commercial Standards are developed by manufacturers, distributors, and users in cooperation with the Commodity Standards Division of the National Bureau of Standards. The purpose of Simplified Practice Recommendations is to eliminate avoidable waste through the establishment of standards of practice for stock sizes and varieties of specific commodities that currently are in general production and demand. The purpose of Commercial Standards is to establish standard methods of test, rating, certification, and labeling of commodities, and to provide uniform bases for fair competition.

The adoption and use of a Simplified Practice Recommendation or Commercial Standard is voluntary. However, when reference to a Commercial Standard is made in contracts, labels, invoices, or advertising literature, the provisions of the standard are enforceable through usual legal channels as a part of the sales contract.

A Simplified Practice Recommendation or Commercial Standard originates with the proponent industry. The sponsors may be manufacturers, distributors, or users of the specific product. One of these three elements of industry submits to the Commodity Standards Division the necessary data to be used as the basis for developing a standard of practice. The Division, by means of assembled conferences or letter referenda, or both, assists the sponsor group in arriving at a tentative standard of practice and thereafter refers it to the other elements of the same industry for approval or for constructive criticism that will be helpful in making any necessary adjustments. The regular procedure of the Division assures continuous servicing of each effective Simplified Practice Recommendation and Commercial Standard, through review and revision, whenever, in the opinion of the industry, changing conditions warrant such action. Simplified Practice Recommendations and Commercial Standards are printed and made available by the Department of Commerce through the Government Printing Office.

\section{COMMERCIAL STANDARD FOR VITREOUS CHINA PLUMBING FIXTURES}

On June 24, 1949, at the instance of the Vitreous China Plumbing Fixtures Association, the recommended revision of the Commercial Standard for Staple Vitreous China Plumbing Fixtures, proposed by the Association and adjusted in accordance with comment from other interested organizations, was circulated to the trade for written acceptance. Those concerned have since accepted and approved the fifth edition, Commercial Standard for Vitreous China Plumbing Fixtures, as shown herein.

Project Manager: A. S. BEst, Commodity Standards Division, National Bureau of Standards.

Technical Adviser: R. F. Geller, Mineral Products Division, National Bureau of Standards. 
COMMERCIAL STANDARD CS20-49

for

\section{VITREOUS CHINA PLUMBING FIXTURES}

(FIFTH EDITION)

\section{CONTENTS}

1. Purpose

2. Scope

3. General requirements .............. 2

4. Detail requirements 3

4.1 Staple water-closet bowls $\ldots$

4.2 Staple tanks $\ldots$

4.3 Staple lavatories $\ldots \ldots$

4.4 Staple urinals

4.5 Staple service sinks

4.6 Staple flat-rim sinks

4.7 Staple flat-rim laundry trays___

5. Method of grading

6. Methods of test

7. Marking and labeling

8. Nomenclature and definitions._._. 29

9. Recommended roughing-in dimension 30

10. Effective date

11. History of project. 32

12. Standing Committee 33

Acceptors

\section{PURPOSE}

1.1 The purpose of this commercial standard is to establish a basic specification for vitreous china plumbing fixtures for the guidance of manufacturers, distributors, and purchaser's; to promote better understanding between suppliers and users; and to serve as a basis for fair competition in furnishing vitreous china plumbing fixtures to meet the principal demands of the trade.

\section{2. $\mathrm{SCOPE}$}

2.1 This commercial standard establishes standard nomenclature, definitions, and method of grading for vitreous china plumbing fixtures, and includes requirements for material, construction, testing, marking and labeling. Standard dimensions and certain general practices are given herein for vitreous china water-closet bowls, tanks, lavatories, urinals, sinks, and laundry trays classed as staple items. Sizes and types of vitreous china plumbing fixtures not specifically mentioned herein are not classed as staple items. 


\section{GENERAL REQUIREMENTS}

3.1 Material.-The plumbing fixtures shall be of vitreous china, and shall meet the absorption and crazing tests given herein. (See paragraphs 6.1 to 6.4 .)

3.2 Thickness.-Vitreous china shall be not less than $1 / 4$ inch thick at any point.

3.3 Glazed surfaces.-The glaze shall be thoroughly fused to the fixture body. All exposed surfaces shall be glazed, except those coming in contact with walls or floors, and except as follows: On lavatories set away from walls, those portions of the rear aprons used for supporting the fixtures in kilns, and also the back of overflows and underside of outlet boss, may be without glaze; the inside and underside of water-closet tanks and the underside of lids need not be glazed. Other fixtures may have unglazed portions at points where supported in the kilns, but such unglazed surfaces shall be located so as not to be visible when the fixture is installed in the normal manner. Inside of trapways of water-closet bowls shall be glazed.

3.4 Grading.-Vitreous china plumbing fixtures shall be graded in accordance with the method given herein. (See pars. 5.1 to 5.6.) The terms "first quality" and "seconds" "shall be used to designate the grades thus determined. "First quality" fixtures shall be in full conformity with this standard, and be free from blemishes and defects to the extent specified in tables 1,2 , and 3 , as applicable.

3.4.1. Careful inspection is employed in each department of manufacture, and each of the imperfections listed herein as acceptable under the "first quality" grading is caused by some unavoidable condition in the manufacturing process. The blemishes permitted in grading do not affect the utility value of the fixture or make it unsafe from a health or sanitary point of view.

3.5 Dimensional tolerances. - Variations from dimensions specified herein shall be not more than 5 percent, plus or minus, except where maximum or minimum limits are specified.

3.6 Trap seal.- The depth of seal for integral traps in all vitreous china fixtures shall be not less than 2 inches, except where greater minimum depths are specified.

3.7 Illustrations.--Illustrations shown herein for various fixtures are for convenience in locating dimensions, and are not intended to indicate designs.

3.7.1 Underlined dimensions in the illustrations are identical for all sizes and types of similar items.

3.8 Colored ware.- - In addition to white, four basic colors are recognized as standard for vitreous china plumbing fixtures, namely, green, blue, ivory, and peach-brown. The shade or tint of each of these four colors is determined by each manufacturer, due to individual production problems.

1 The designation "seconds" in this edition replaces the word "culls" as used in preceding editions of this standard. 


\section{DETAIL REQUIREMENTS}

\subsection{Staple Water-Closet Bowls.}

4.1.1 Fiushing.-Water-closet bowls covered by this standard shall pass the flushing test specified in paragraph 6.5 , in order to be considered as having a satisfactory flushing action.

4.1.2 Spud size.-The standard size for spuds on all water-closet bowls shall be as follows: 2 inches for all water-closet bowls operated
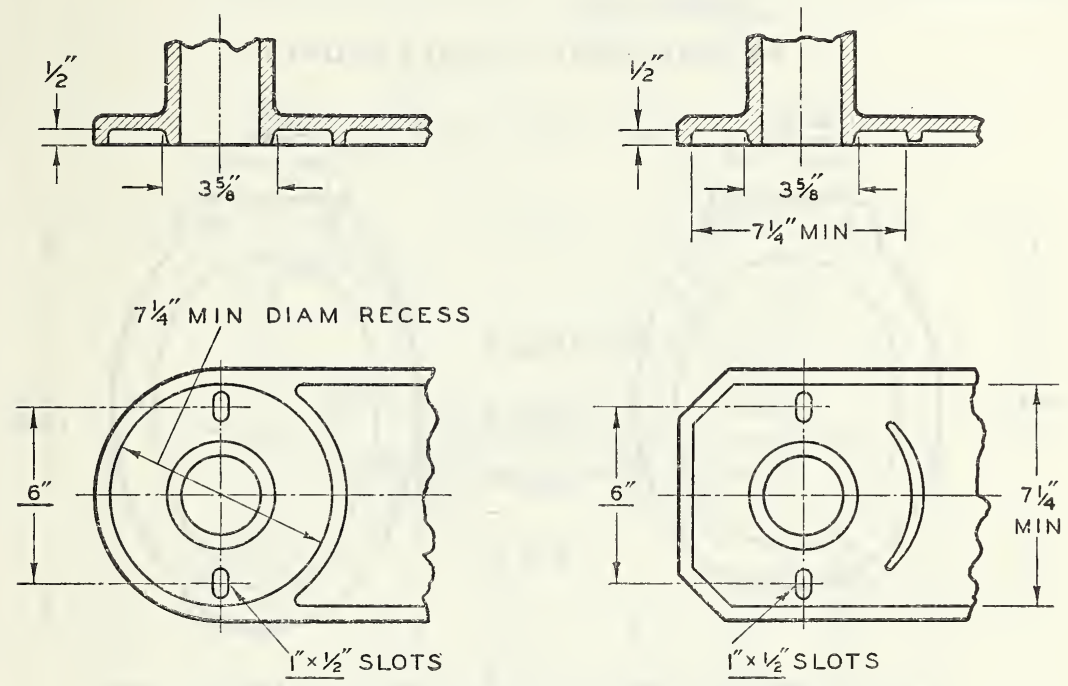

Figure 1. Outlet of water-closet bowl and pedestal urinal.

Note 1. Designs of bases may vary from those shown.

Note 2. Underlined dimensions in all illustrations are identical for all sizes and types of similar items.

under low tanks; $1 \frac{1}{2}$ inches for all water-closet bowls operated under high tanks or direct flushing valves.

4.1.3 Outlets.-The outlets of water-closet bowls shall conform to dimensions shown in figure 1.

4.1.4 "Juvenile" height water-closet bowls shall be 13 inches minimum, $13 \frac{1}{2}$ inches maximum from floor to top of rim, and shall have the same top contour as regular bowls (smaller or "baby" bowls are considered special).

4.1.5 Combinations. - The following water-closet combinations shall be considered staple:

(a) Close-coupled water-closet combination.-Water-closet bowl with separate tank secured to and supported by the watercloset bowl.

(b) Direct-flushing-valve water-closet combination.-Water-closet bowl with direct flushing valve.

(c) Integral water-closet combination.-Single piece of china comprising water-closet bowl and tank. 
(d) Low-tank water-closet combination.-Water-closet bowl and low separately supported tank, the bottom of which is mounted with respect to the water-closet bowl approximately as indicated in figure 3 herein. (See also fig. 6.)

4.1.6 Designation of combinations.-Water-closet combinations shall be designated as above, with the type of water-closet bowl inserted, as for example "Direct-flushing-valve siphon-jet water-closet combination," or "Direct-flushing-valve reverse-trap water-closet combination."

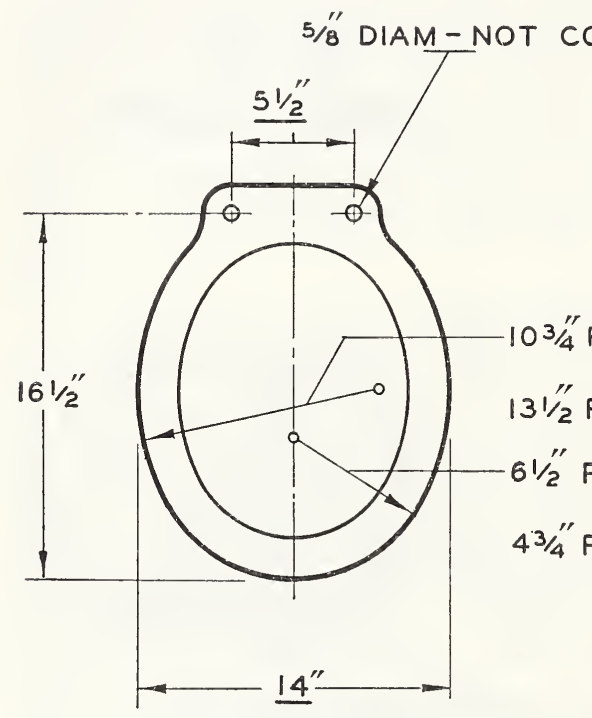

REGULAR

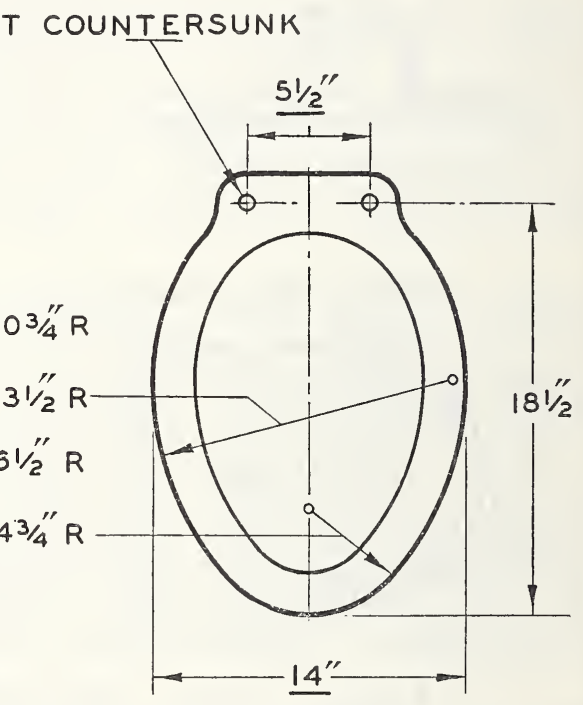

ELONGATED

FIGURE 2. Top contour for water-closet bowls.

4.1.7 Top contour for water-closet bowls.-Regular and elongated water-closet bowls shall have top contours as shown, respectively, in figure 2.

4.1.8 Wash-down water-closet bowl.-The term "wash-down" shall be applied to water-closet bowl having back supply (except for use as part of integral or close-coupled combinations); integral flushing rim and jet; a minimum water surface of 8 by 7 inches; a minimum water seal of $2 \frac{1}{2}$ inches; and a siphon trapway at the front of closet which shall pass a 1132-inch-diameter solid ball. Minimum weight of back supply bowl-30 pounds; minimum weight of close-coupled bowl-34 pounds. Bowls shall be as shown in figures 3,4 , and 5 .

4.1.9 Reverse-trap water-closet bowi.-The term "reverse-trap" shall be applied to water-closet bowls having back supply (except for use as part of integral or close-coupled combinations); integral flushing rim and jet; a minimum water surface of 9 by 8 inches; a minimum water seal of $2 \frac{1}{2}$ inches; and a siphon trapway at the rear of closet which shall pass a 1\%2-inch-diameter solid ball. Minimum weight of 

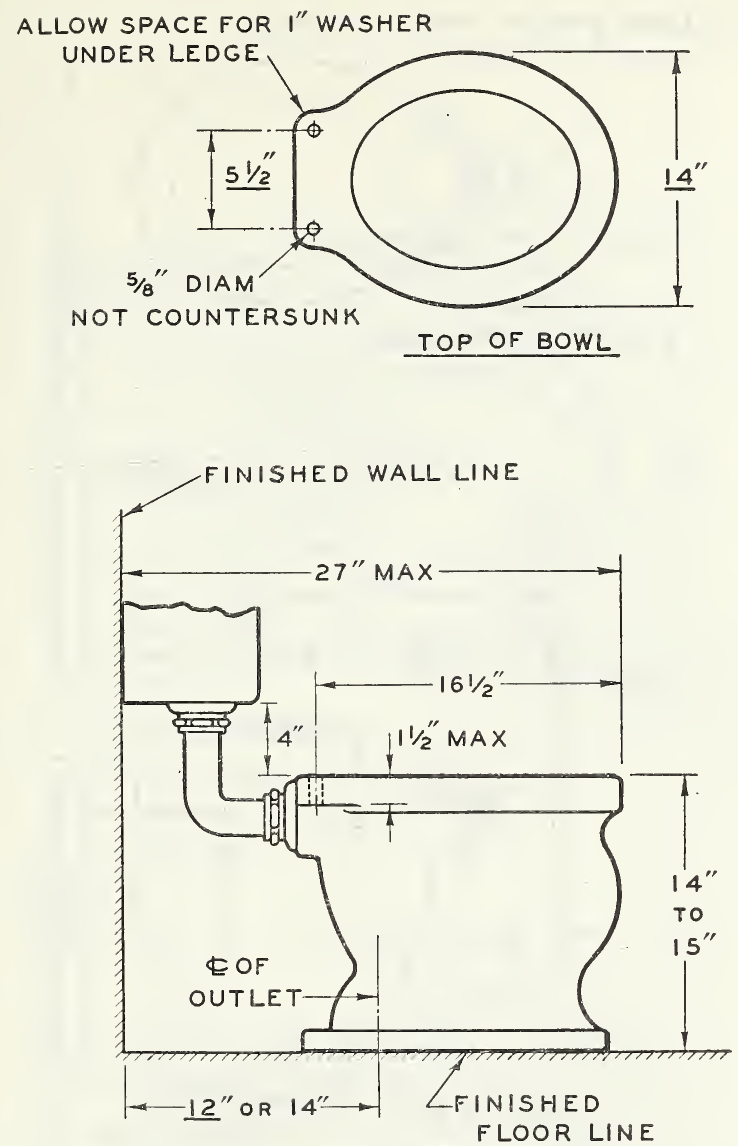

Figure 3. Low-tank wash-down water-closet combination.

back supply bowl-30 pounds; minimum weight of close-coupled bowl-34 pounds; minimum weight of integral combination less cover-70 pounds. Bowls shall be as shown in figures $6,7,8$ and 9 .

4.1.10 Siphon-jet water-closet bowl.-The term "siphon-jet" shall be applied to the water-closet bowl having top supply (except for use as part of close-coupled combination); integral flushing rim and jet; a minimum water surface of 12 by 10 inches; a minimum depth of seal of 3 inches; and a siphon trapway at the rear of closet which shall pass a $2 \frac{1}{8}$-inch-diameter solid ball. Minimum weight of regular top-supply bowl-40 pounds; minimum weight of close-coupled bowl - 40 pounds; minimum weight of juvenile height bowl -40 pounds. Bowls shall be as shown in figures 10 and 11.

4.1.11 Blow-out wall-hanging water-closet bowls for direct flush valve.-The term "blow-out wall-hanging" shall be applied to wall closet bowls having top supply; integral flushing rim and jet; a minimum water surface of 12 by 10 inches; a minimum depth of seal of 3 


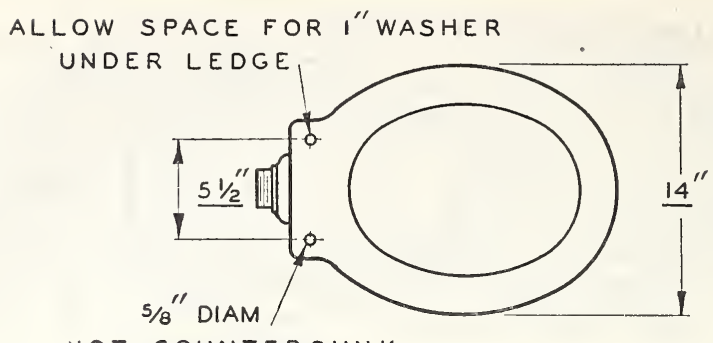

NOT COUNTERSUNK

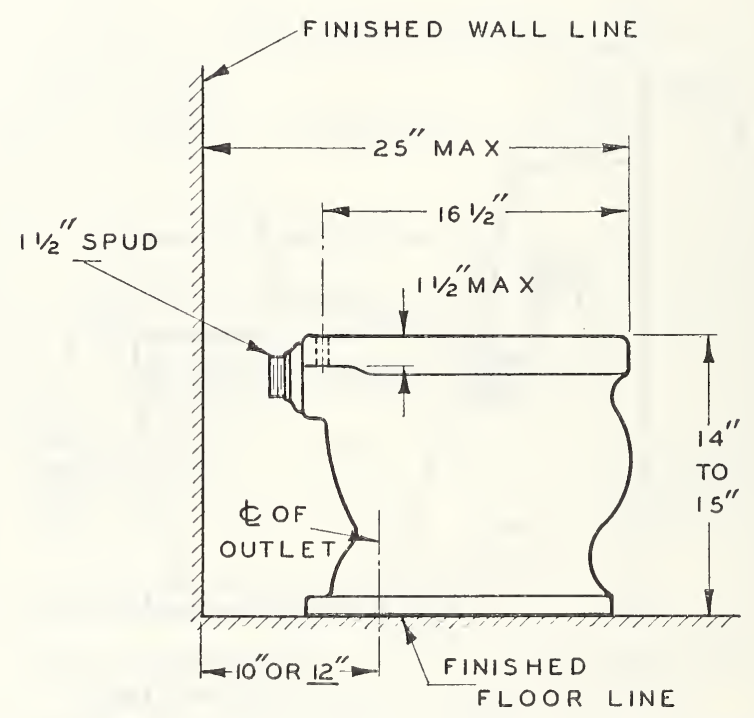

Figure 4. Wash-down water-closet bowl for direct flush valve.

inches; and a trapway which shall pass a 21/8-inch-diameter solid ball. Minimum weight 40 pounds. Bowl shall be as shown in figure 12 . 4.1.12 Siphon-jet wall-hanging water-closet bowl for direct flush valve.-The term "siphon-jet wall-hanging" shall be applied to wall closet bowls having top supply; integral flushing rim and jet; a minimum water surface of 12 by 10 inches; a minimum depth of seal of 3 inches; and a siphon trapway which shall pass a $2 \frac{11}{8}$-inch-diameter solid ball. Minimum weight 45 pounds. Bowl shall be as shown in figure 13 . 

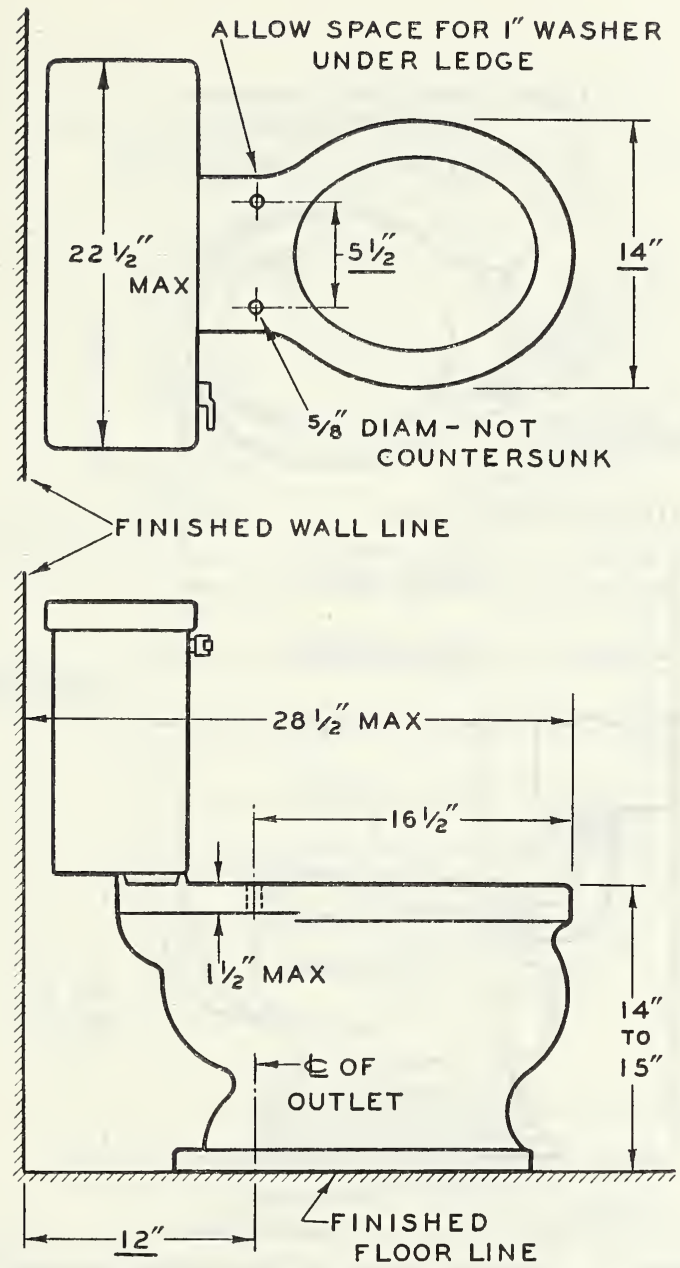

Figure 5. Close-coupled wash-down water-closet combination. 


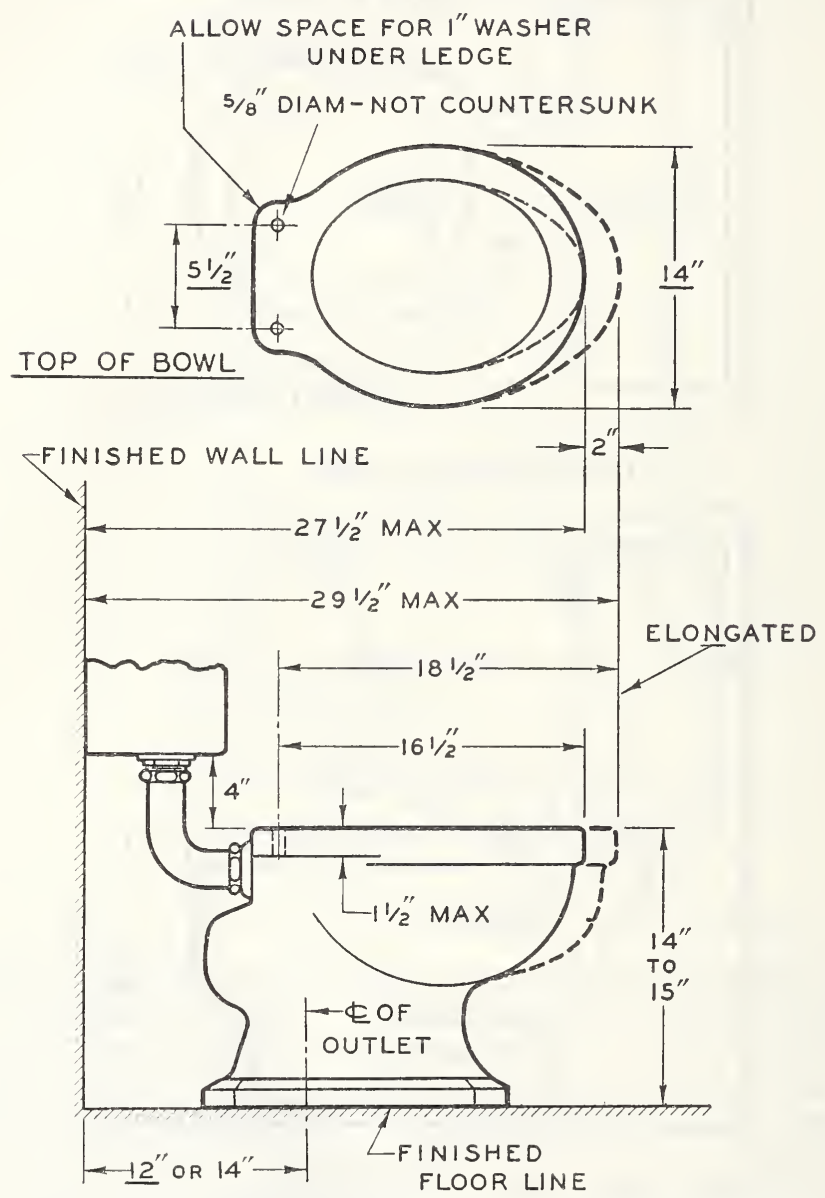

FIgURE 6. Low-tank reverse trap water-closet combination. 


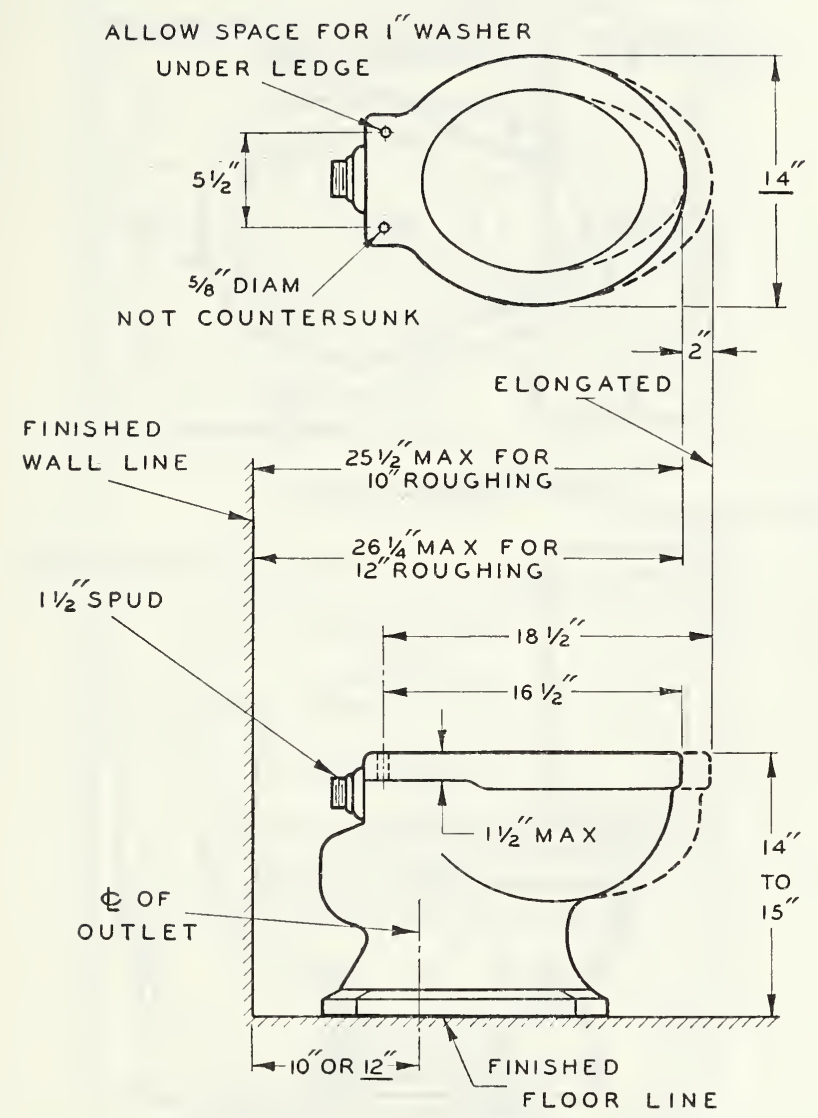

FIGURE 7. Reverse-trap water-closet bowl for direct flush valve. 


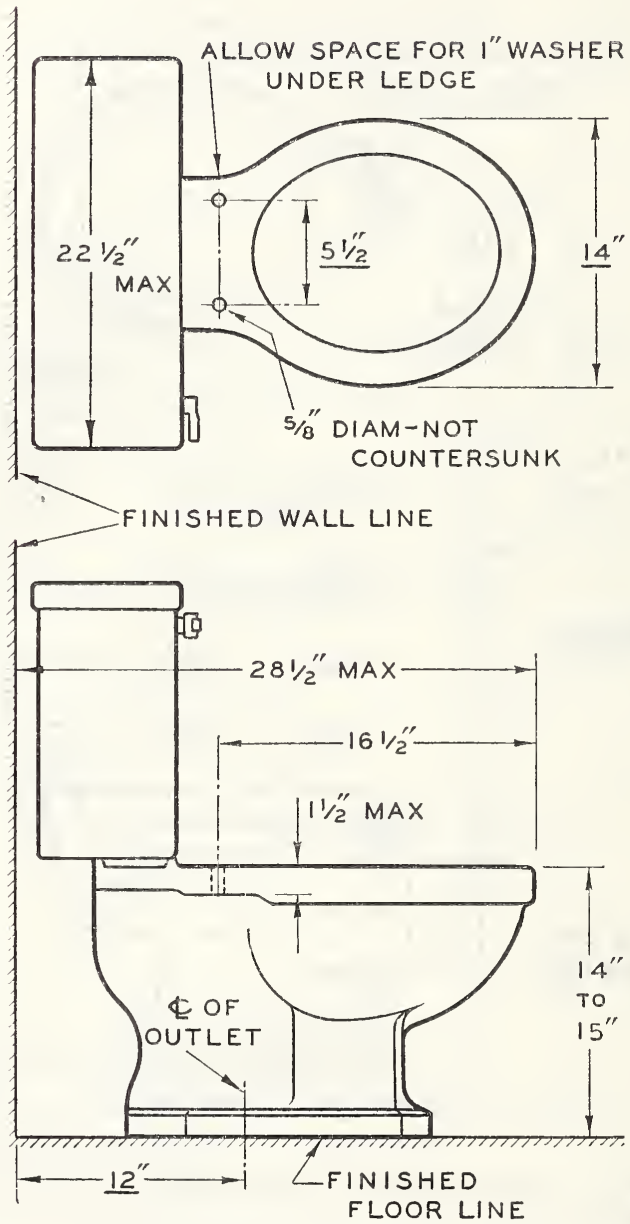

FIGURE 8. Close-coupled reverse-trap water-closet combination. 


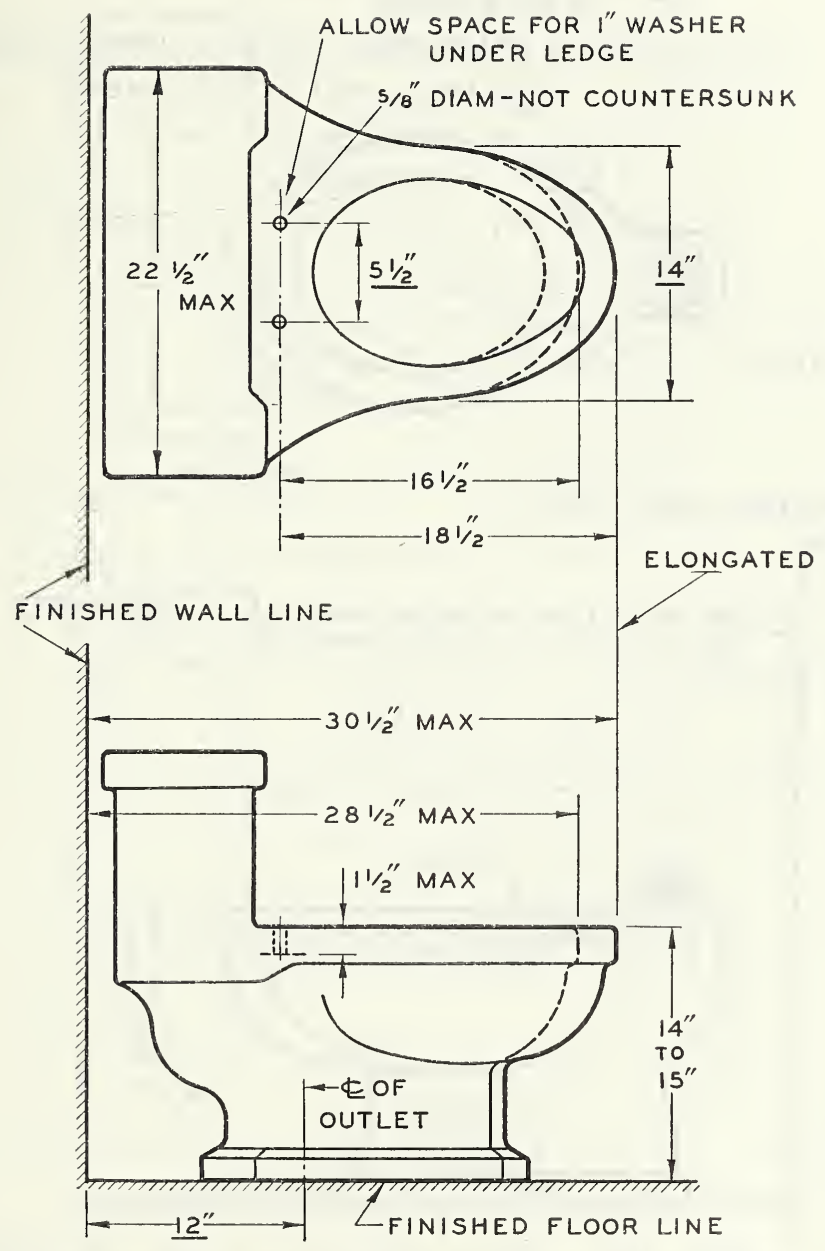

FIGURE 9. Integral reverse-trap water-closet combination. 


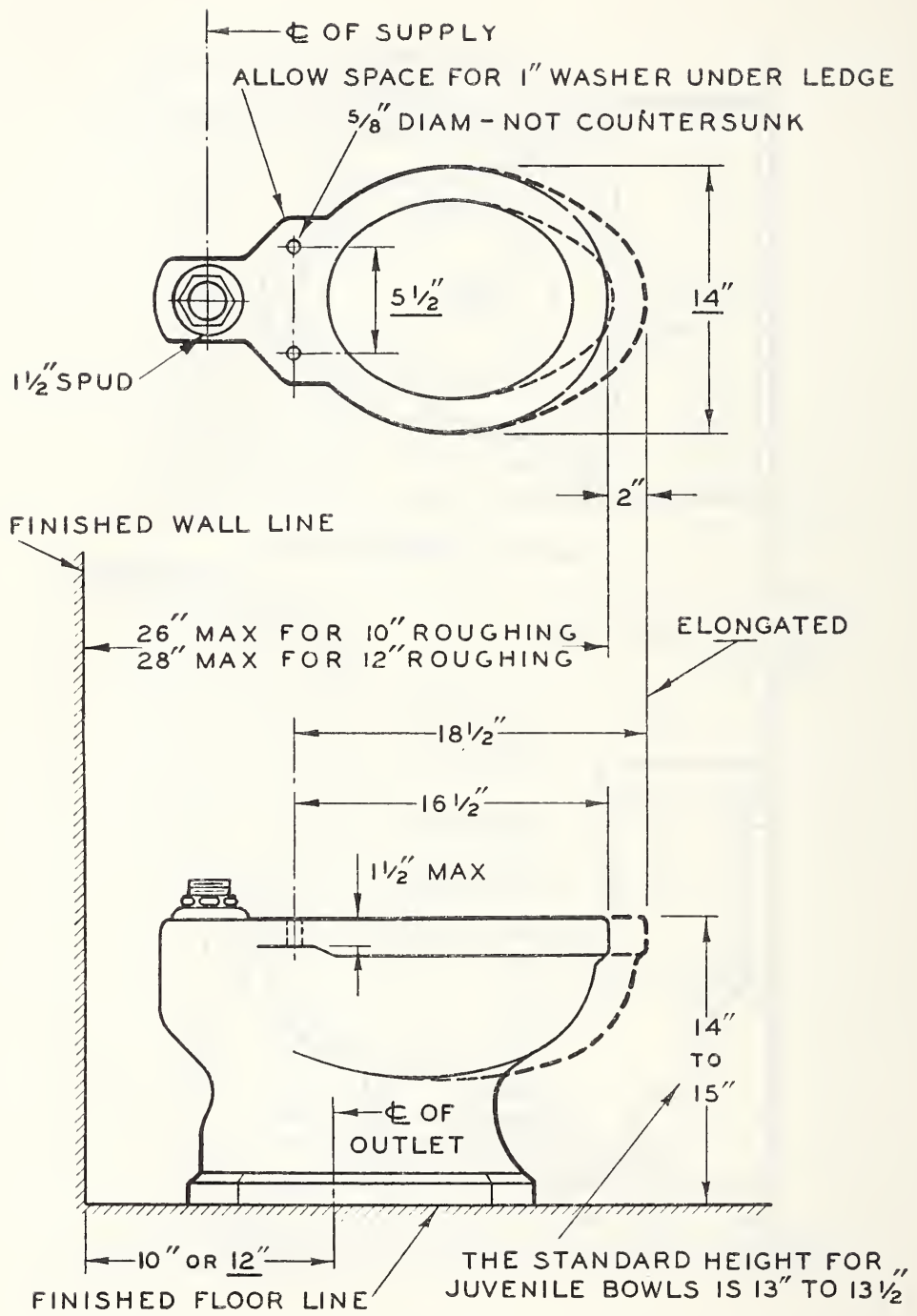

FIGURE 10. Siphon-jet water-closet bowl for direct flush valve. 


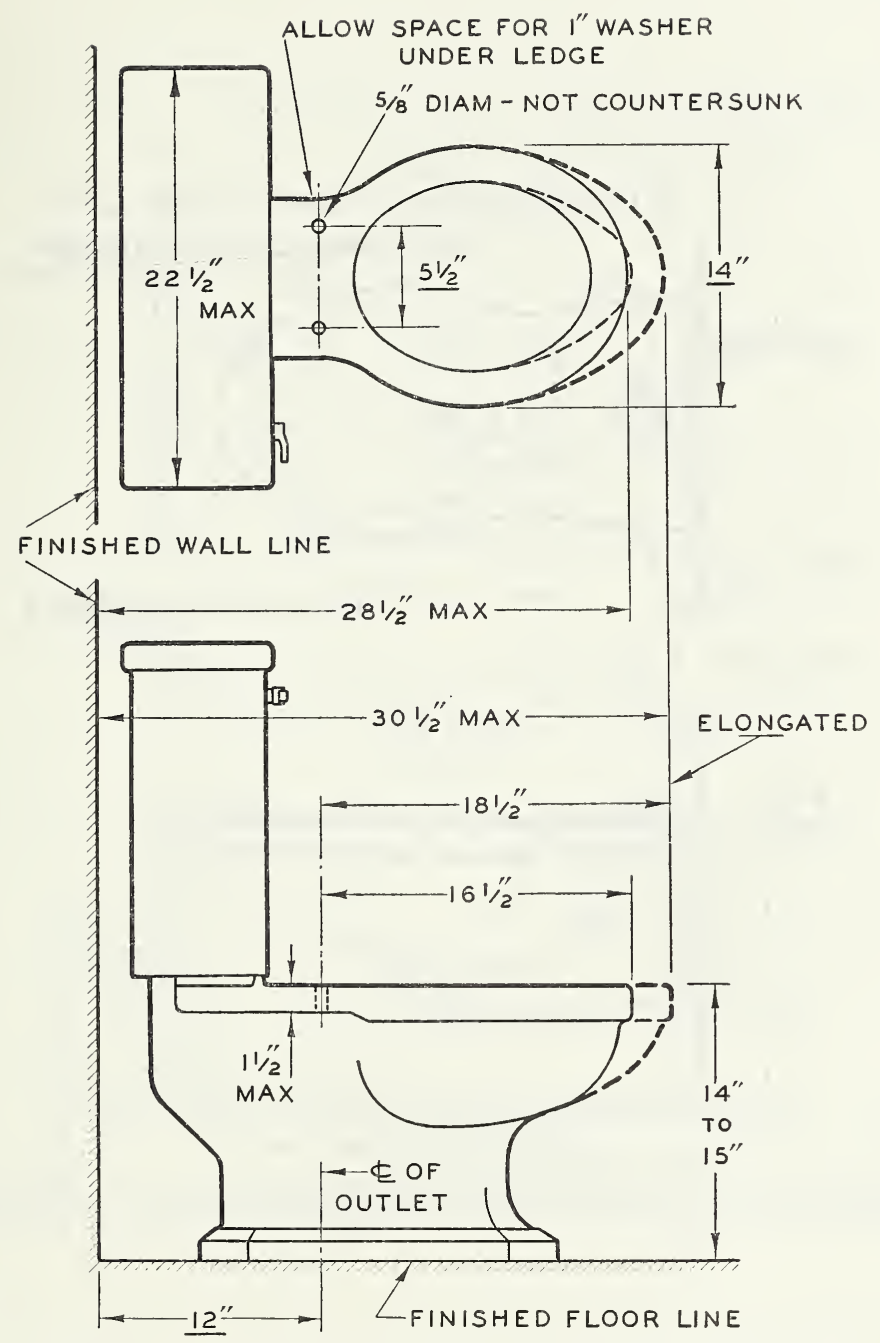

FIgURE 11. Close-coupled siphon-jet water-closet combination. 


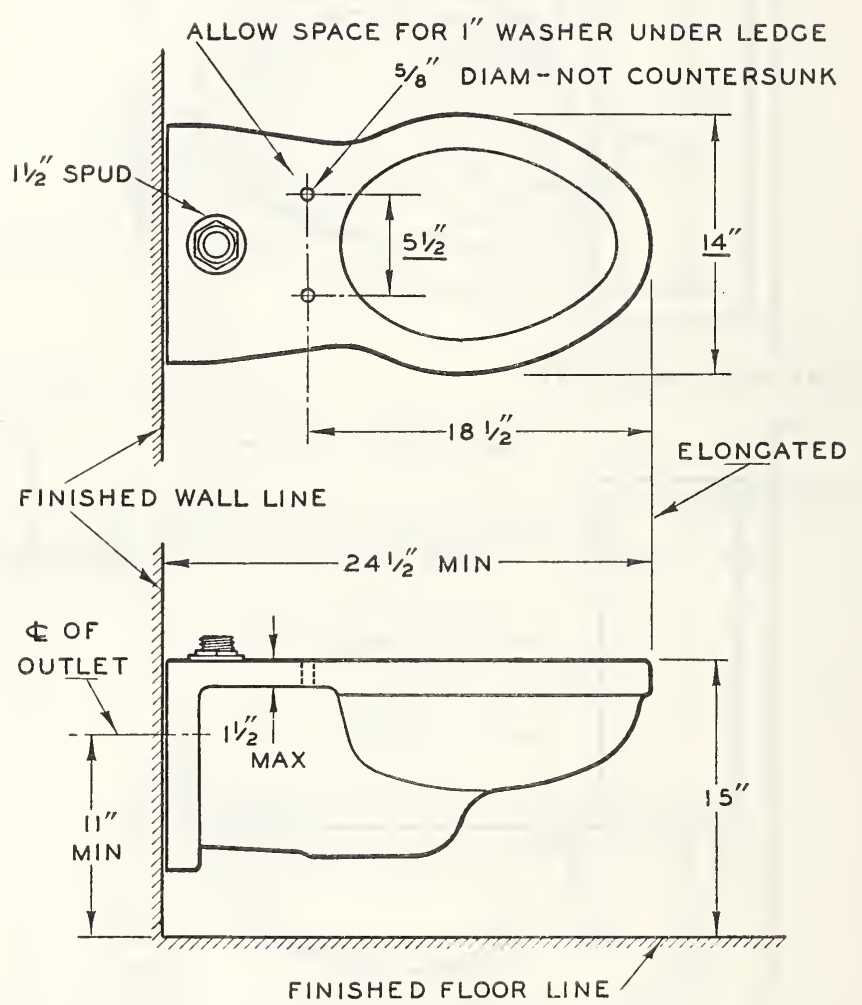

FIGURE 12. Blow-out wall-hanging water-closet bowl for direct flush valve. 


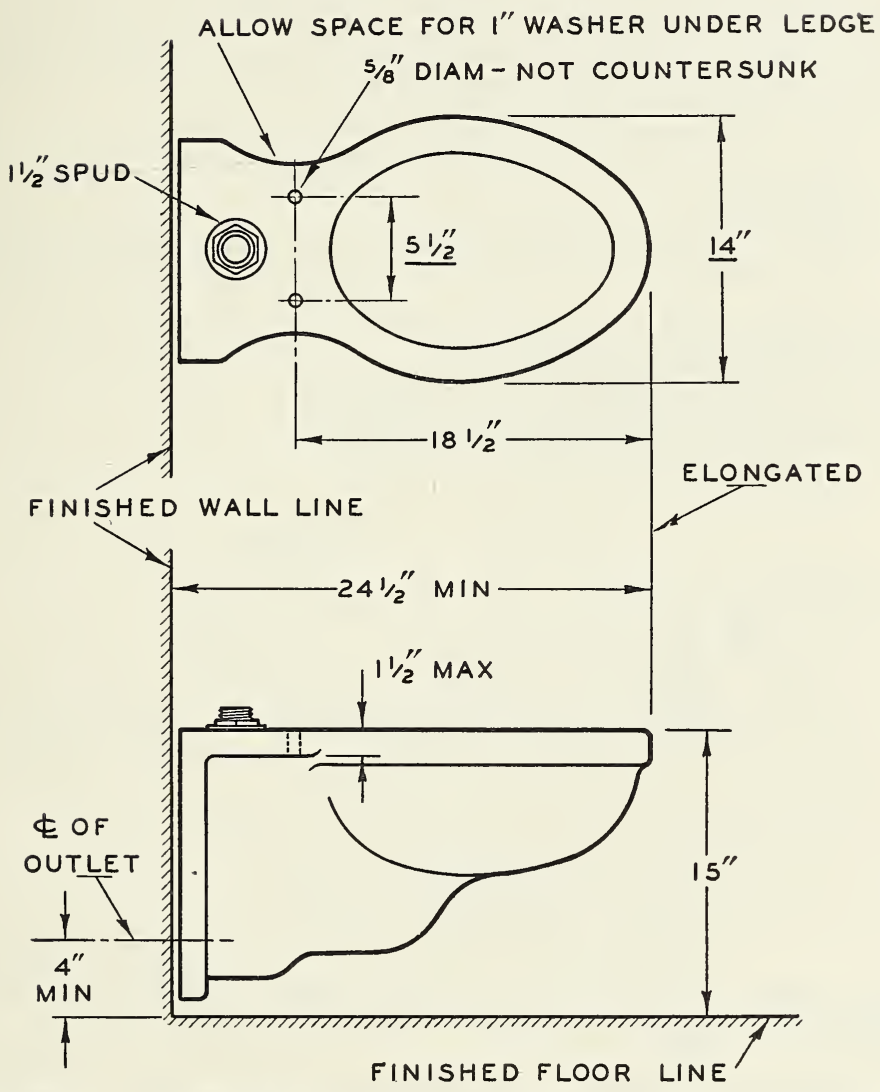

FIGURE 13. Siphon-jet wall-hanging water-closet bowl for direct flush valve. 


\subsection{Staple Tanks.}

4.2.1 Staple low wall-hanging tank shall be as shown in figure 14 .

4.2.2 The following shall be furnished with "trimmed" staple low wall-hanging tank:

One elevated float valve (ball cock) with refill tube and float ball rod.

One float.

One tank flush valve (Douglas pattern) with $2 \frac{1}{2}$-inch rubber ball and 1-inch minimum O. D. overflow tube.

One single-acting operating lever with handle set horizontally.

One 2-inch O. D. elbow flush connection 5 by 6 inches maximum, complete with nuts and rubber washers.

Two wood screws with washers or hooks for tank.

The following item is optional according to understanding between buyer and seller:

One 2-inch spud escutcheon, where required. (Supply pipe and supply pipe escutcheon are listed as separate fittings, not as trim.)

4.2.3 High tanks for urinals shall have automatic flush valves. The following sizes are staple:

No. 1. To flush approximately $1 \frac{1}{2}$ gallons.

No. 3. To flush approximately 3 gallons.

No. 4. To flush approximately $4 \frac{1}{2}$ gallons.
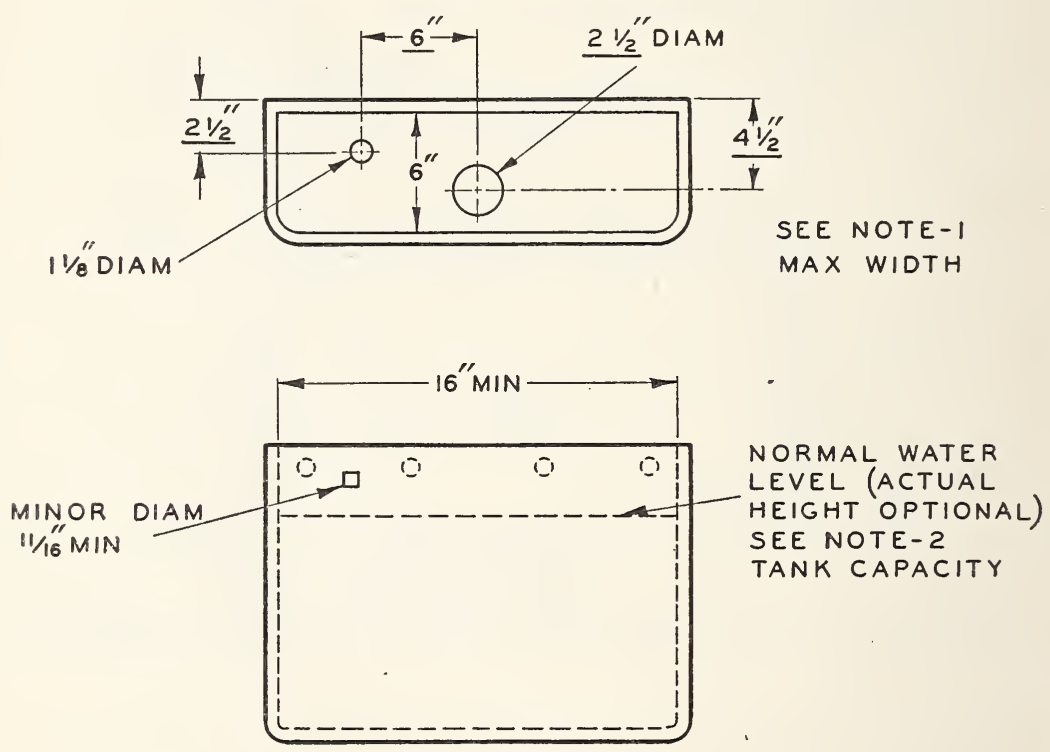

DETAILS OF TANK WITH COVER REMOVED

FIgURe 14. Staple low tank (wall-hanging).

Note 1. Tank width over cover, $22 \frac{1}{2}$ in. maximum.

Note 2. Tank capacity shall be sufficient to flush properly the bowl with which it is furnished. 


\subsection{Staple Lavatories.}

4.3.1. Lavatory shall be of one-piece vitreous china with oval, rectangular, or D-shaped bowl; apron and front antisplash rim. Lavatories shall have integral overflow at front or back with crosssectional area not less than $1 \frac{1}{8}$ square inches at every point. Overflow point of slab shall be not more than $1 / 2$ inch above slab surface at lowest point of any faucet bearing. The location of holes for faucets, spouts, drains, etc., shall be as shown in figures 15, 16, 17, and 18 .

4.3.2 Faucet-hole spacing for exposed center-set fittings mounted horizontally.-The standard faucet-hole spacing is 4 inches center-tocenter, in top of or in front of the shelf or the ledge in either shelf-back or ledge-back lavatories; and in lavatories with or without back.

4.3.3 Faucet-hole spacing for separate faucets and combination fittings.- The standard faucet-hole spacing is 8 inches center-to-center, in top of or in front of the shelf or the ledge in either shelf-back or ledge-back lavatories; and in all staple pattern lavatories with or without back, except where impractical and where commercial practice requires 10 - or 12 -inch spacing.

4.3.4. Shelf-back lavatories.-The sizes and dimensions of shelfback lavatories are not standardized, but the applicable requirements of this standard apply in all other respects. They are made in varying sizes ranging from 12 by 12 inches to 30 by 22 inches, the most popular of which are 18 by 15, 19 by 17, 20 by 18, 22 by 18, and 24 by 20 inches; and up to 26 by 14 inches in several space-saver sizes. These items are not illustrated.

\subsection{Staple Urinals.}

4.4.1 Stall urinal shall be of one-piece vitreous china with straight front and integral flushing rim, as shown in figure 19. There are two standard sizes of plain seam covers for stall urinals, one for urinals installed on 21-inch centers, and one for 24 -inch centers. It is recommended that winged seam covers be eliminated.

4.4.2 Pedestal urinal shall be of vitreous china with integral flush rim, siphon jet, top inlet, and pedestal base with siphon trap, all molded in the ware. The depth of the water seal shall be not less than 2 inches and the siphon trapway shall pass a solid ball not less than $11 / 2$ inches in diameter. See figure 20.

4.4.3 Wall-hanging wash-out urinal shall be of vitreous china and of wash-out type with integral flushing rim, trap, and extended shields, all molded in the ware. Fixture may have integral cast strainer or open trapway. The water seal shall not be less than 2 inches. Urinal shall be as shown in figure 21.

\subsection{Staple Service Sinks.}

4.5.1 Vitreous china service sink shall be of one-piece vitreous china with integral back and with space behind back for supplies. The service sink shall be as shown in figure 22.

\subsection{Staple Flat-Rim Sinks.}

4.6.1 Vitreous china flat-rim sink shall be of one-piece vitreous china, rectangular in shape, as shown in figure 23. 


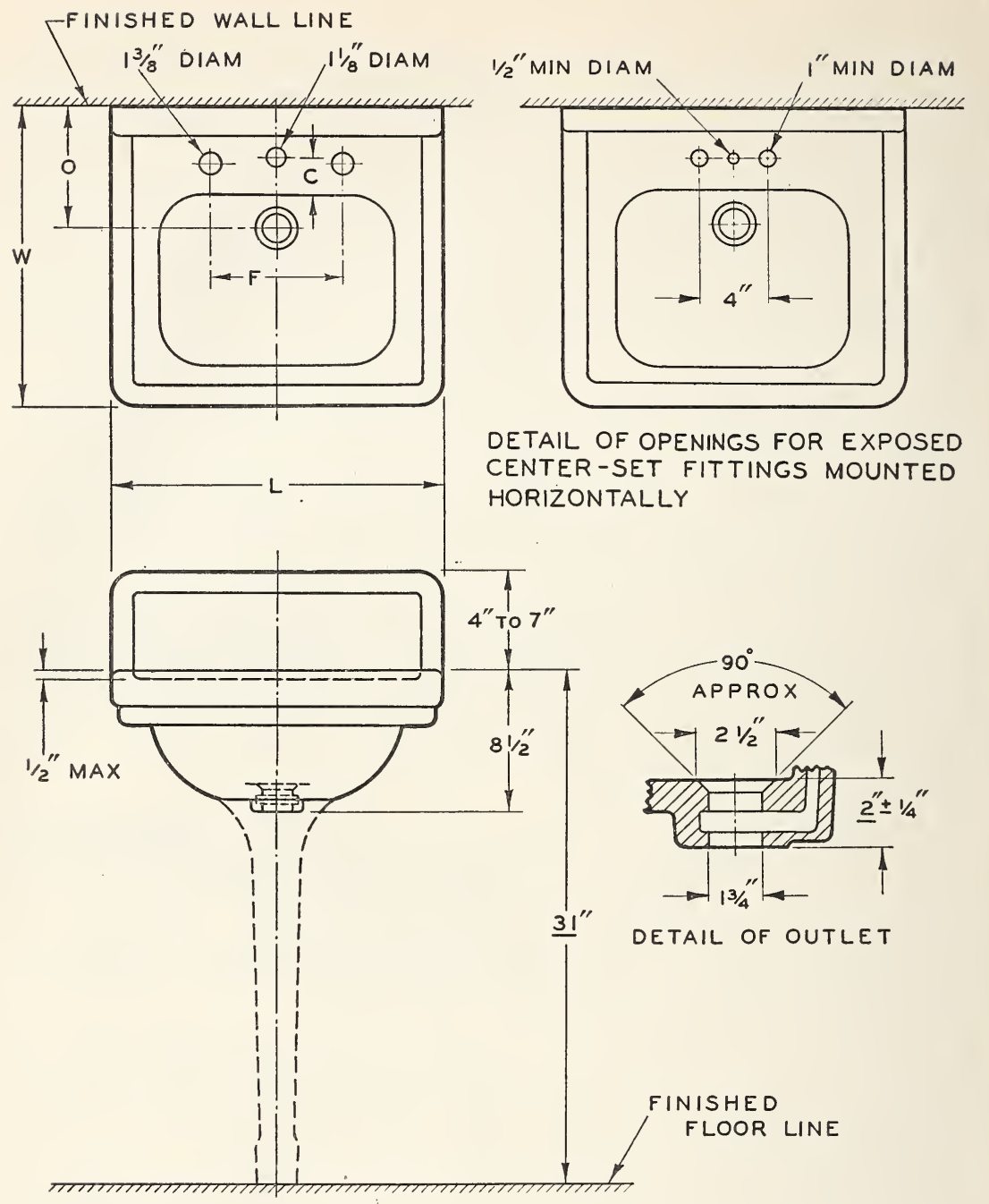

\begin{tabular}{|c|c|c|c|c|c|}
\hline NOMINAL SIZE & L & $w$ & $\begin{array}{c}F \\
\text { NOTE }\end{array}$ & $\begin{array}{c}\text { O } \\
\text { NOTE } 2\end{array}$ & $\begin{array}{c}\text { C } \\
\text { NOTE } 3\end{array}$ \\
\hline $20^{\prime \prime} \times 18^{\prime \prime}$ & $20^{\prime \prime}$ & $18^{\prime \prime}$ & $8^{\prime \prime}$ & $71 / 2$ & $21 / 21$ \\
\hline $24^{\prime \prime} \times 20^{\prime \prime}$ & $24^{\prime \prime}$ & $20^{\prime \prime}$ & $8^{\prime \prime}$ & $8^{\prime \prime}$ & $21 / 2$ \\
\hline
\end{tabular}

FIGURE 15. Straight-front lavatories with back.

Note 1. Dimension $\mathrm{F}$ may be 10 or 12 in. (see par. 4.3.3).

Note 2. Tolerance $\pm 3 / 4 \mathrm{in}$. on dimension 0 .

Note 3. Tolerance $\pm 1 / 2$ in. on dimension C. 


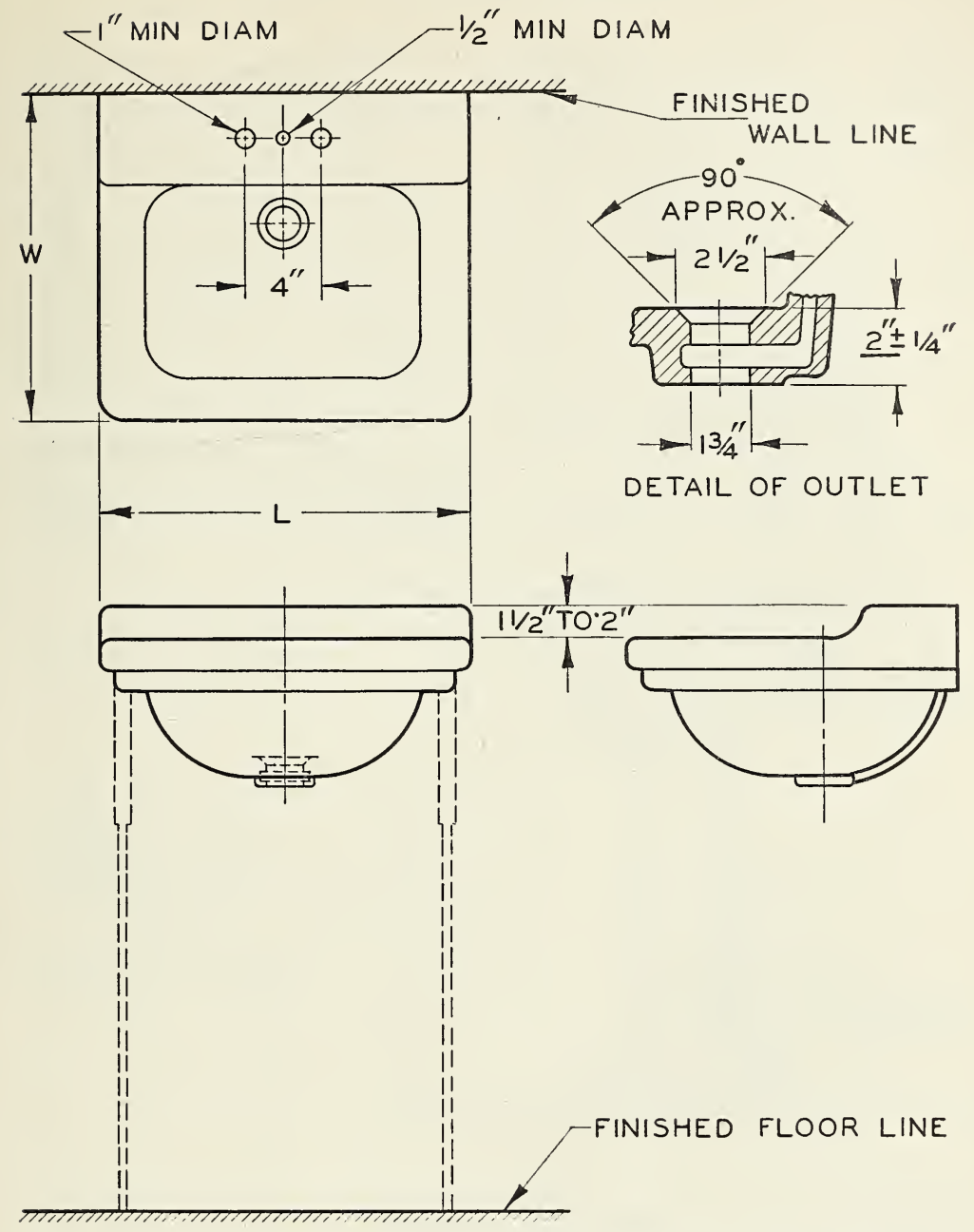

\begin{tabular}{|l|c|c|l|}
\hline NOMINAL SIZE & $L$ & W & \multicolumn{1}{|c|}{ SUPPORTS } \\
\hline \hline $18^{\prime \prime} \times 15^{\prime \prime}$ & $18^{\prime \prime}$ & $15^{\prime \prime}$ & WITH OR WITHOUT LEGS \\
\hline $19^{\prime \prime} \times 17^{\prime \prime}$ & $19^{\prime \prime}$ & $17^{\prime \prime}$ & WITH OR WITHOUT LEGS \\
\hline $20^{\prime \prime} \times 18^{\prime \prime}$ & $20^{\prime \prime}$ & $18^{\prime \prime}$ & WITH OR WITHOUT LEGS \\
\hline $24^{\prime \prime} \times 20^{\prime \prime}$ & $24^{\prime \prime}$ & $20^{\prime \prime}$ & WITH LEGS \\
\hline
\end{tabular}

Figure 16. Ledge-back lavatories. 


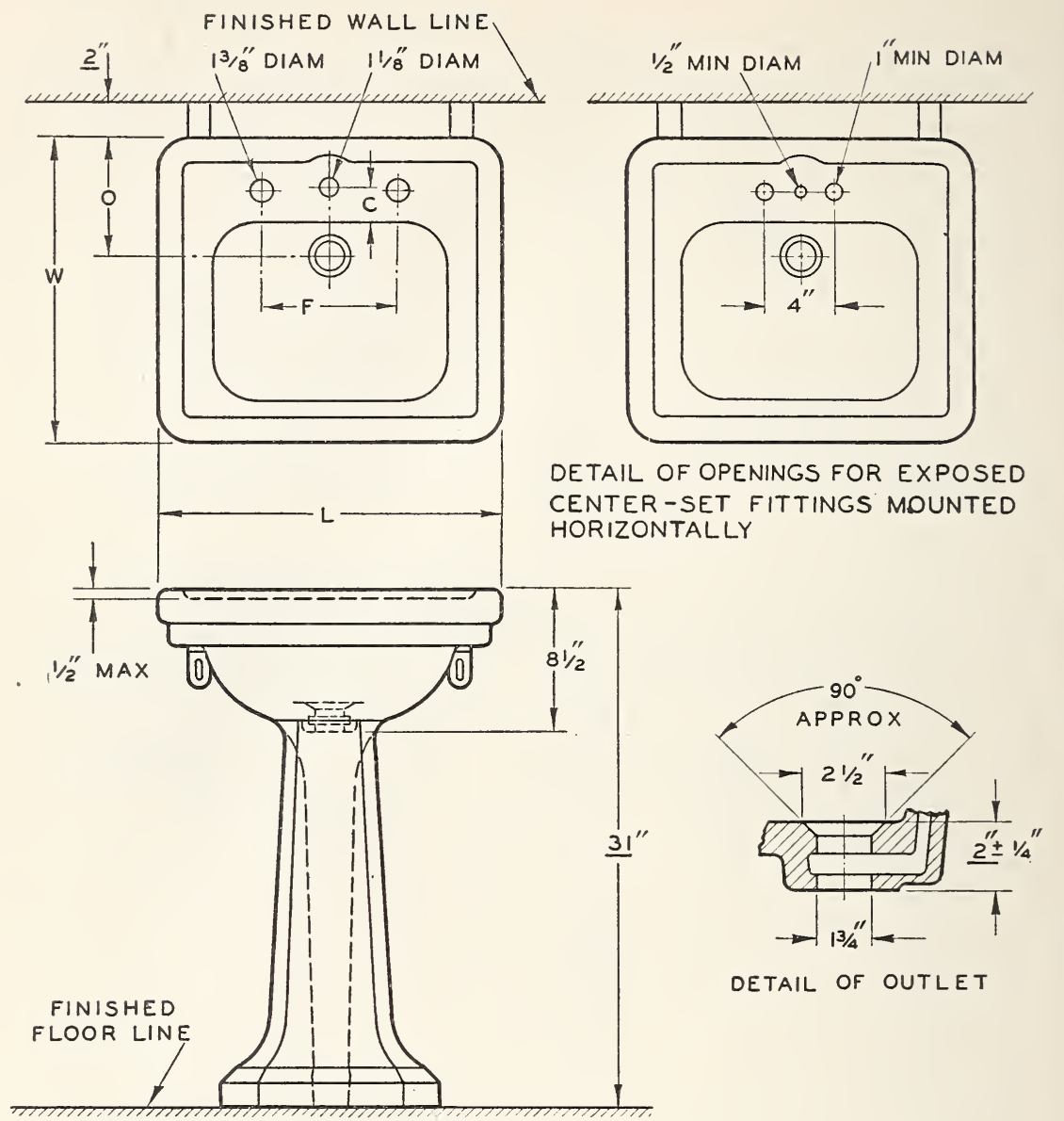

\begin{tabular}{|c|c|c|c|c|c|}
\hline $\begin{array}{c}\text { NOMINAL } \\
\text { SIZE }\end{array}$ & L & W & $\begin{array}{c}\text { F } \\
\text { NOTE 1 }\end{array}$ & $\begin{array}{c}\text { O } \\
\text { NOTE 2 }\end{array}$ & $\begin{array}{c}\text { C } \\
\text { NOTE 3 }\end{array}$ \\
\hline $20^{\prime \prime} \times 18^{\prime \prime}$ & $20^{\prime \prime}$ & $18^{\prime \prime}$ & $8^{\prime \prime}$ & $71 / 2$ & $21 / 2$ \\
\hline $24^{\prime \prime} \times 20^{\prime \prime}$ & $24^{\prime \prime}$ & $20^{\prime \prime}$ & $8^{\prime \prime}$ & $8^{\prime \prime}$ & $21 / 2$ \\
\hline $27^{\prime \prime} \times 22^{\prime \prime}$ & $27^{\prime \prime}$ & $22^{\prime \prime}$ & $8^{\prime \prime}$ & $81 / 2$ & $21 / 2$ \\
\hline
\end{tabular}

Figure 17. Slab-type lavatories.

Note 1. Dimension F may be 10 in. or 12 in. (see par. 4.3.3).

Note 2. Tolerance $\pm 3 / 4$ in. on dimension $O$.

Note 3. Tolerance $\pm 1 / 2$ in. on dimension $\mathrm{C}$. 

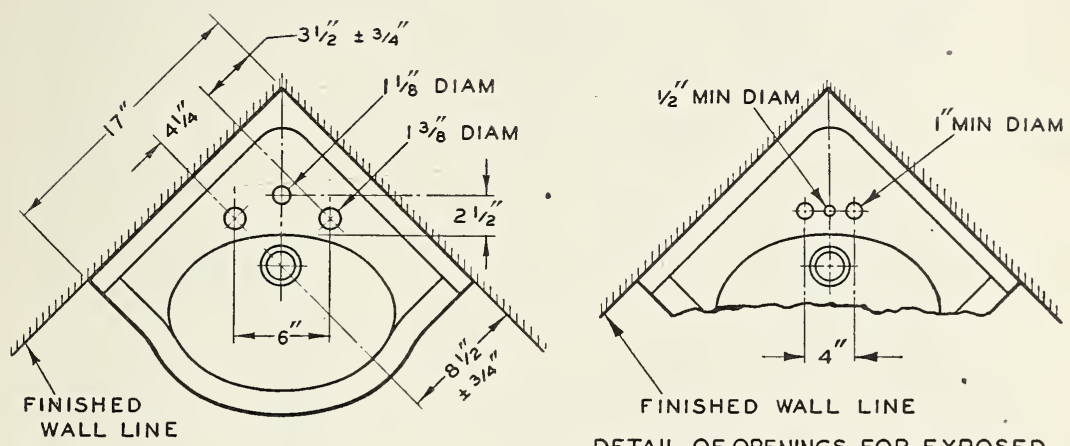

DETAIL OF OPENINGS FOR EXPOSED CENTER - SET FITTINGS MOUNTED HORIZONTALLY
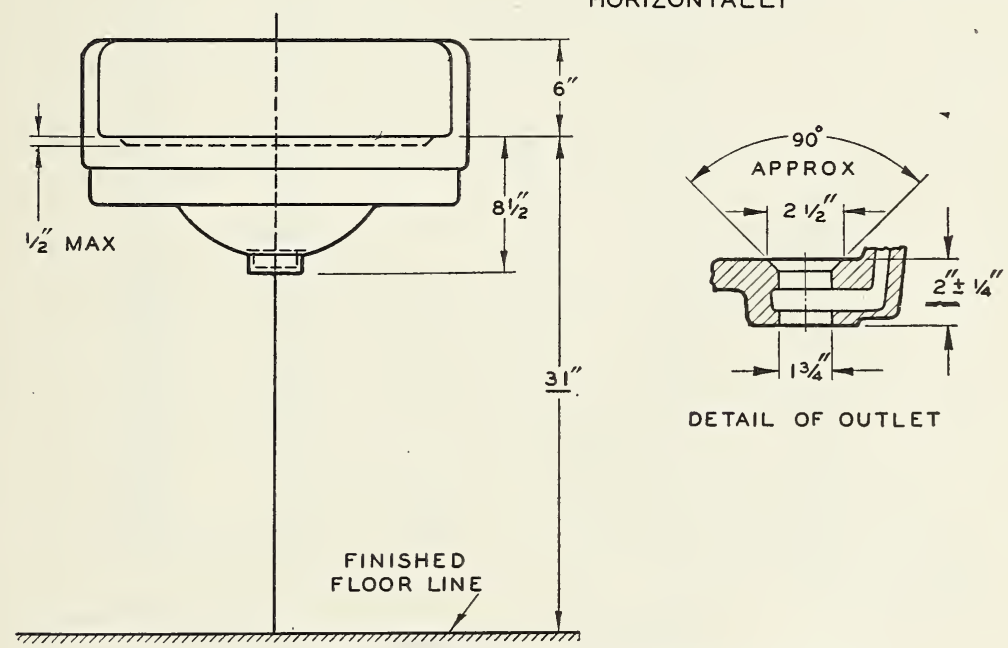

DETAIL OF OUTLET

FIGURe 18. Round-front corner lavatory with back. 

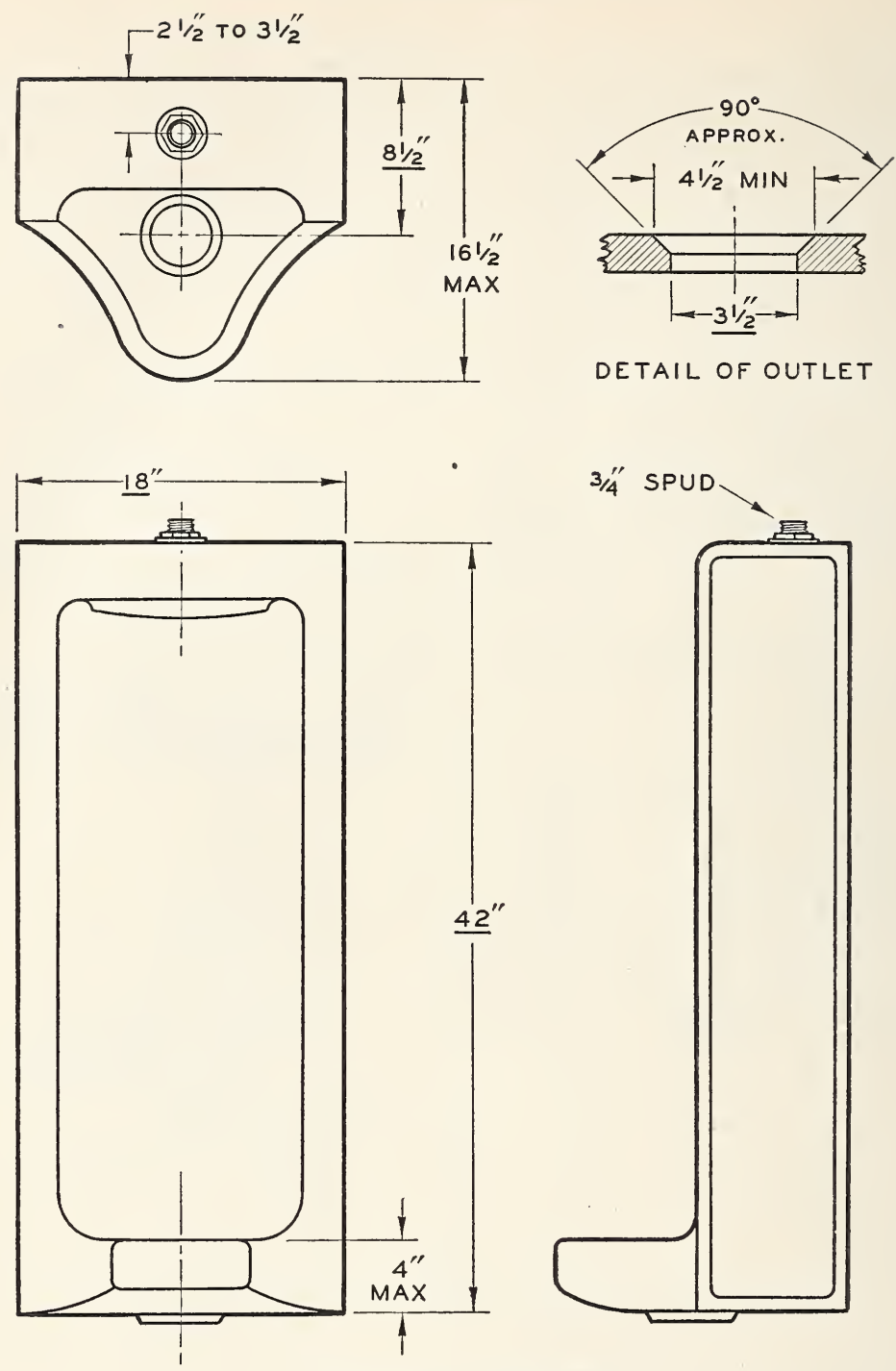

Figure 19. Stall urinal. 


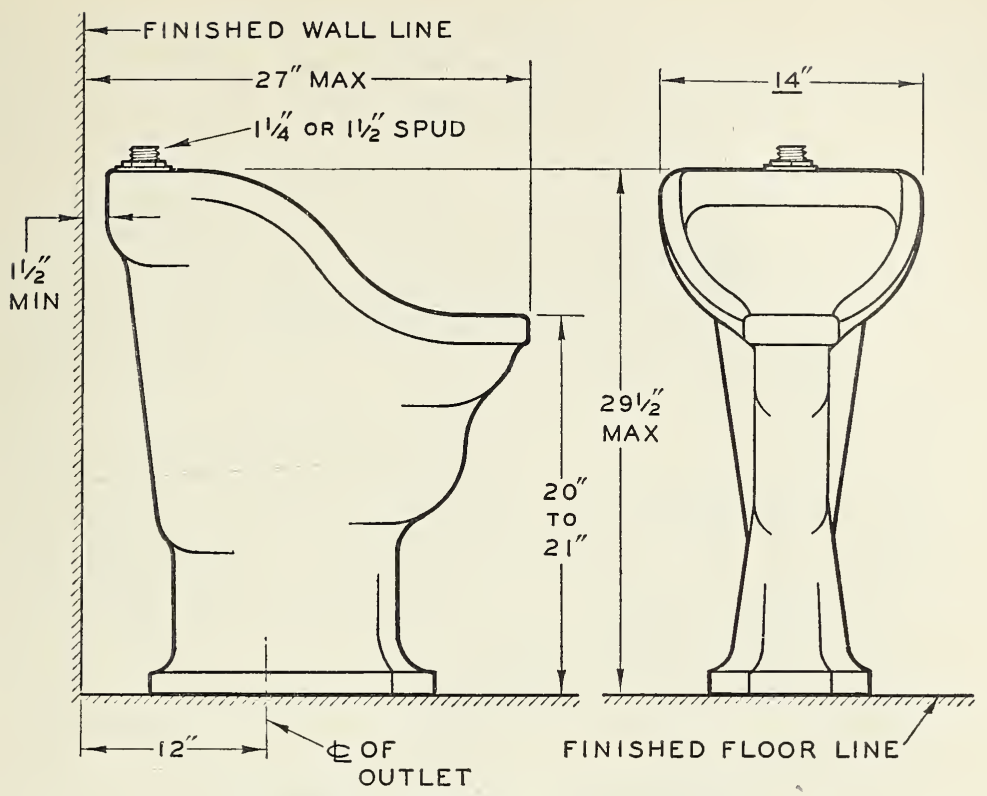

Frgure 20. Top-supply pedestal urinal.

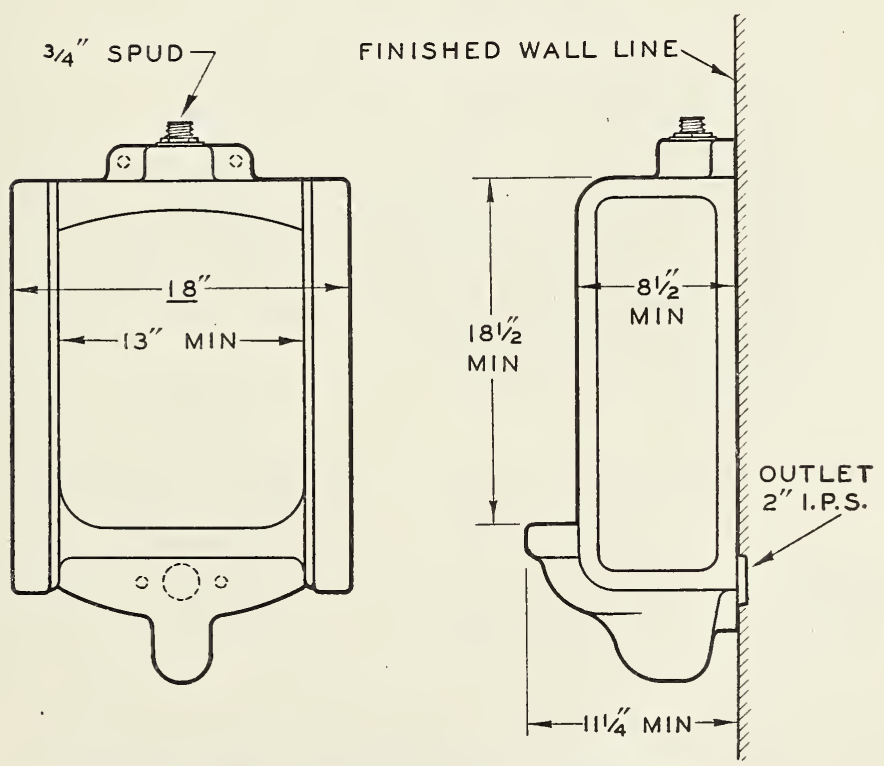

FIgURE 21. Wall-hanging wash-out urinal. 


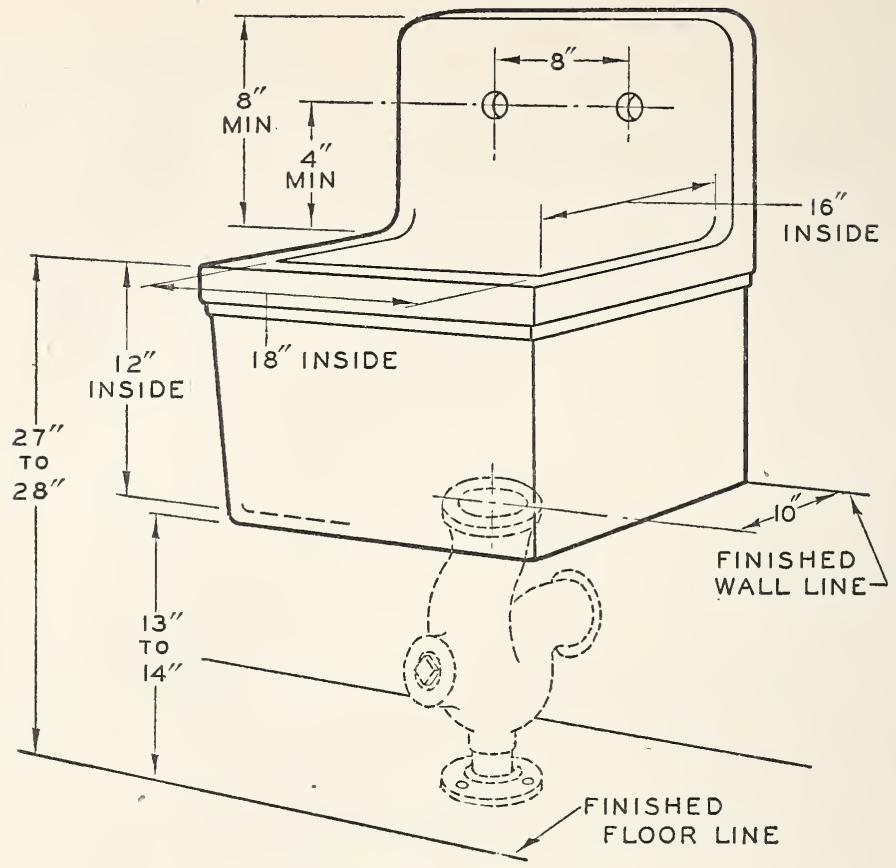

Figure 22. Service sink.
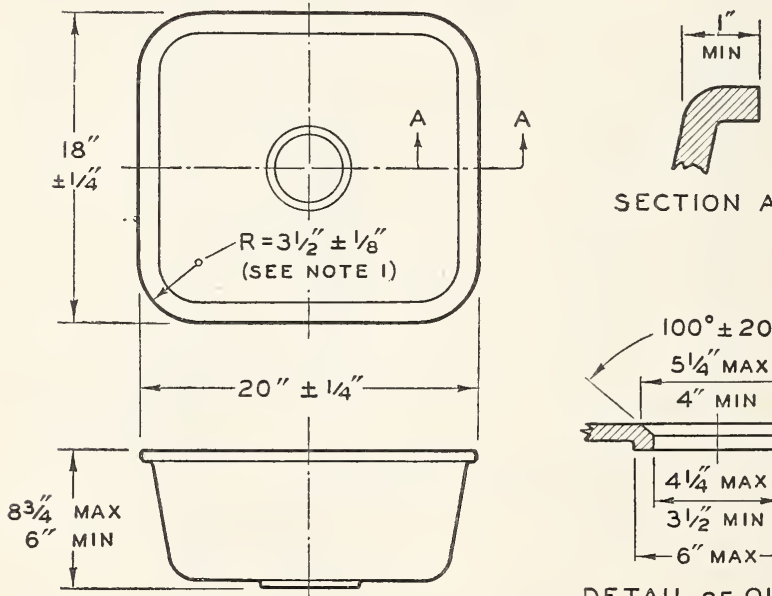

SECTION A-A

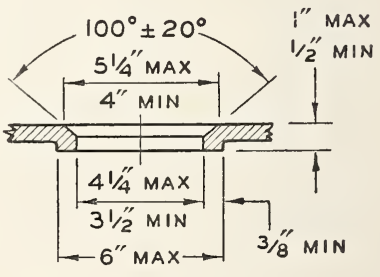

DETAIL OF OUTLET

NOTE I. RADIUS "R" MAY BE $43 / 8$ " $1 / 8$ " AS AN ALTERNATE. NOTE 2, IF OTHER SIZES ARE MADE THEY SHALL CONFORM TO ALL DIMENSIONS SHOWN ABOVE EXCEPT LENGTH AND WIDTH. FIgURE 23. Flat-rim sink. 


\subsection{Staple Flat-Rim Laundry Trays.}

4.7.1 Vitreous china flat-rim laundry tray shall be of one-piece vitreous china, rectangular in shape, as shown in figure 24 .
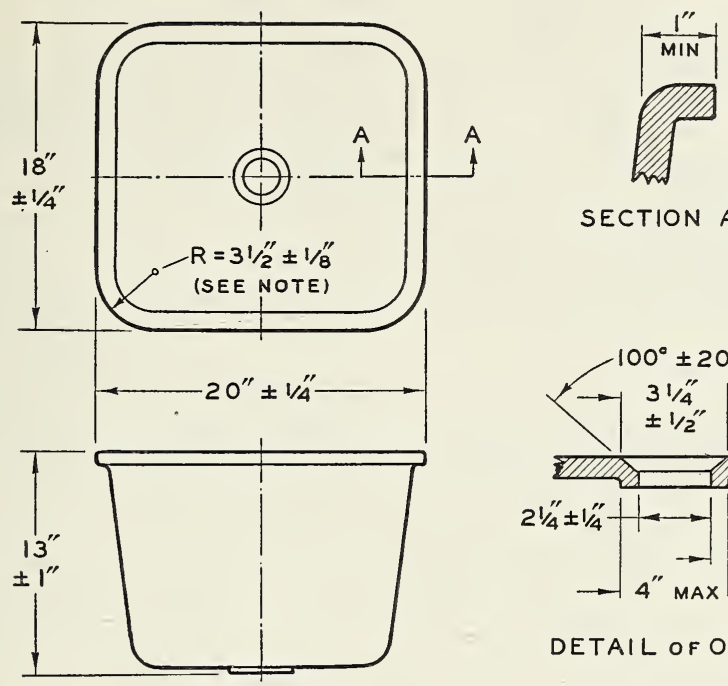

SECTION A-A

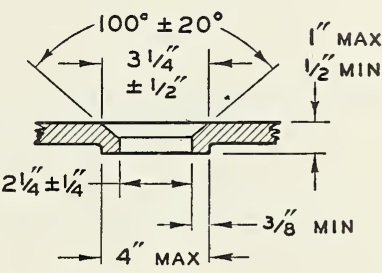

DETAIL OF OUTLET

NOTE.-DIMENSION "R" MAY BE $43 / 8$ " $\pm 1 / 8$ " AS AN ALTERNATE.

FIGURE 24. Flat-rim laundry tray.

\section{METHOD OF GRADING}

5.1 It is not intended that inspectors shall measure or count any blemishes except in case of doubt, since, with practice, dimensional limits and numbers can be readily gaged by eye.

5.2 Water-closet bowls shall be examined for minor blemishes with the eyes of the observer about 2 feet directly above the rim while the fixture is rocked to either side and backward to an angle of about $45^{\circ}$. Minor blemishes not observed in this operation are assumed to be on unseen surfaces.

5.3 Water-closet bowls, urinals, high tanks, sinks, laundry trays, service sinks and all pedestals and legs shall be graded in accordance with the maximum blemishes listed in table 1.

5.4 Low tanks shall be graded in accordance with the maximum blemishes listed in table 2. Examinations shall be made with the eyes of the observer about 2 feet from the surface observed. No blemishes on the inside surface shall be counted. Minor blemishes on the outside surface, where hidden by the cover, shall not be counted.

5.5 Lavatories shall be graded in accordance with the maximum number of blemishes listed in table 3. Lavatories shall be examined with the eyes of the observer about 2 feet from the surface observed. (Pedestals and legs shall be graded the same as water-closet bowls.) 
TABLE 1. Maximum blemishes for first-quality vitreous china water-closet bowls, urinals, high tanks, sinks, laundry trays, service sinks, and all pedestals and legs

\begin{tabular}{|c|c|c|}
\hline Location & Blemish or defect & Maximum permitted \\
\hline General. & $\left\{\begin{array}{l}\text { Dull or eggshell finish. } \\
\text { Wavy finish } \\
\text { Excess glaze.-. } \\
\text { Warpage: } \\
\quad \text { Water closets...... } \\
\quad \text { Other fixtures. } \\
\text { Large blisters } \\
\text { Dunts } \\
\text { Projections. }\end{array}\right.$ & $\begin{array}{l}\text { Not over } 4 \text { square inches. } \\
\text { Not more than } 4 \text { square inches. } \\
\text { Not more than } 1 / 8 \text { inch thick in well. } \\
\text { Not noticeably warped when seat is attached. } \\
\text { Not more than } 1 / 4 \text { inch per foot; total warpage } \\
\text { not more than } 1 / 2 \text { inch. } \\
\text { Not more than two. } \\
\text { None allowed. } \\
\text { Do. }\end{array}$ \\
\hline Flushing surface. & $\left\{\begin{array}{l}\text { Exposed body } \\
\text { Fire check } \\
\text { Spots, blisters, and pinholes. } \\
\text { Bubbles or specks... }\end{array}\right.$ & $\begin{array}{l}\text { None allowed. } \\
\text { Do. } \\
\text { No segregation; a total of not over } 10 . \\
\text { Not over } 10 \text { in } 1 \text { "pottery square"; a total of } \\
\text { not over } 25 .\end{array}$ \\
\hline Visible surface... & $\left\{\begin{array}{l}\text { Exposed body } \\
\text { Fire check } \\
\text { Spots, blisters, and pinholes.... } \\
\text { Bubbles or specks. }\end{array}\right.$ & $\begin{array}{l}\text { Not over } 1 / 4 \text { inch on foot; not over } 1 / 8 \text { inch on } \\
\text { more prominent surfaces (maximum di- } \\
\text { mension). } \\
\text { Not over } 1 / 4 \text { inch long. } \\
\text { No segregation; a total of not over } 10 \text {. } \\
\text { Not over five in one "pottery square"; a } \\
\text { total of not over } 25 \text {. }\end{array}$ \\
\hline
\end{tabular}

TABLE 2. Maximum blemishes for first-quality vitreous china low tanks and covers

\begin{tabular}{|c|c|c|}
\hline Location & Blemish or defect & Maximum permitted 1 \\
\hline General. . & $\left\{\begin{array}{l}\text { Warpage-_. } \\
\text { Dunts }\end{array}\right.$ & $\begin{array}{l}\text { Not noticeably warped. } \\
\text { None allowed. }\end{array}$ \\
\hline \multirow{3}{*}{ Visible surface.-. } & (Dull or eggshell finish & \multirow{3}{*}{$\begin{array}{l}\text { None allowed on front; not over } 2 \text { square } \\
\text { inches on each side. } \\
\text { Not more than } 4 \text { square inches. } \\
\text { Not over } 1 / 8 \text { inch (maximum dimension). } \\
\text { None on front, one on each side not over } \\
1 / 4 \text { inch long. } \\
\text { No segregation; a total of not over } 10 . \\
\text { Not over five in one "pottery square;" a } \\
\text { total of not over } 25 \text {. }\end{array}$} \\
\hline & $\left\{\begin{array}{l}\text { Wavy finish } \\
\text { Exposed body } \\
\text { Fire check }\end{array}\right.$ & \\
\hline & Spots, blisters, and pinholes...... & \\
\hline
\end{tabular}

1 Covers shall show not more than 50 percent of the number of blemishes listed in table 2 .

TABLE 3. Maximum blemishes for first-quality vitreous china lavatories

\begin{tabular}{|c|c|c|}
\hline Location & Blemish or defect & Maximum permitted \\
\hline General. & 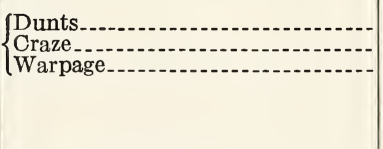 & $\begin{array}{l}\text { None allowed. } \\
\text { Do. } \\
\text { Warpage of slab out of horizontal plane not } \\
\text { to exceed } 1 / 4 \text { inch on all sizes. (The same } \\
\text { allowable deviation to apply to lavatories } \\
\text { with back, when attached to wall.) }\end{array}$ \\
\hline $\begin{array}{l}\text { Service space, top of } \\
\text { slab, inside of bowl } \\
\text { and front of apron. }\end{array}$ & $\left\{\begin{array}{l}\text { Dull or eggshell finish } \\
\text { Exposed body } \\
\text { Fire check } \\
\text { Spots, blisters, and pinholes } \\
\text { Bubbles and specks } \\
\text { Polishing mark }\end{array}\right.$ & $\begin{array}{l}\text { One allowed, not over } 1 / 2 \text { inch. } \\
\text { None allowed. } \\
\text { Do. } \\
\text { No segregation; a total of not more than four. } \\
\text { Do. } \\
\text { Not more than two allowed. }\end{array}$ \\
\hline $\begin{array}{l}\text { Face of integral back } \\
\text { and sides. }\end{array}$ & $\left\{\begin{array}{l}\text { Dull or eggshell finish } \\
\text { Exposed body } \\
\text { Large blisters } \ldots \ldots \\
\text { Fire check } \\
\text { Spots, blisters, and pinholes......... } \\
\text { Bubbles or specks. }\end{array}\right.$ & $\begin{array}{l}\text { One allowed, not over } 1 / 2 \text { inch. } \\
\text { None over } 1 / 2 \text { inch, not more than two al- } \\
\text { lowed. } \\
\text { Not more than two on either side or on back; } \\
\text { a total of not more than three. } \\
\text { None on back; one only allowed, which may } \\
\text { be on either side. } \\
\text { Not more than three on back or on either } \\
\text { side, a total of not more than six. } \\
\text { No segregation; a total of not more than six. }\end{array}$ \\
\hline
\end{tabular}


5.6 For all vitreous china plumbing fixtures not specifically mentioned in the foregoing, the grading rules for water-closet bowls shall apply.

\section{METHODS OF TEST}

6.1 Absorption test.-Either the red-ink test or the boiling test as described below may be used, but in cases of dispute the boiling test shall be used.

6.2 Red-ink test.-A fractured piece of material taken from any part of a vitreous-china plumbing fixture, after being immersed in red aniline ink of good color strength for 1 hour, shall not show any discoloration through the glaze and shall not show absorption, when broken, to a depth greater than $1 / 8$ inch below the surface of fracture at any point.

6.3 Boiling test.

6.3.1 The test sample shall be three fragments taken from any part of the fixture. Each fragment shall have approximately 5 square inches of surface area and a thickness of not more than $5 / 8$ inch. The pieces shall be dried to constant weight at $230^{\circ} \pm 10^{\circ} \mathrm{F}$, and shall then be stored in a desiccator until cooled to room temperature. After reaching room temperature, each specimen shall be weighed on a balance to an accuracy of $0.1 \mathrm{gram}$.

6.3.2 The weighed pieces shall then be placed in distilled water in a suitable vessel, supported so that they shall not be in contact with the heated bottom of the container, and boiled for 2 hours. They shall then be allowed to remain in the water for 20 hours, then each dried slightly with a damp towel to remove excess water, and reweighed to an accuracy of 0.1 gram.

6.3.3 The absorption shall be reported as a percentage of the weight of the dried sample. The percentage for each test piece is obtained by dividing the weight of the water absorbed, in grams, by the weight of the dried test piece, in grams, and multiplying by 100 . The average absorption of the three test pieces shall not exceed $1 / 2$ of 1 percent.

6.4 Crazing test.-A test specimen not more than $5 / 8$ inch in thickness by 5 inches square shall be suspended in a solution of equal portions, by weight, of anhydrous calcium chloride and water and then boiled at a constant temperature of $230^{\circ} \pm 5^{\circ} \mathrm{F}^{\circ}$ for $1 \frac{1}{2}$ hours. It shall then be removed and immediately plunged into an ice-water bath at $36^{\circ}$ to $38^{\circ} \mathrm{F}$ until chilled. The specimen shall then be soaked for 12 hours in a concentrated solution of methylene-blue dye, after which it shall be examined for craze lines as indicated by penetration of the blue dye. No crazing is permissible.

6.5 Flushing test for water-closet bowls.

6.5.1 Paper.- The standard size paper to be used in this test is $4 \frac{1}{2}$ by 5 inches. If smaller or larger size is used, the load should be increased or decreased proportionately, based on the square inches of surface per sheet.

6.5.2 For interfold (pack type) toilet paper, six sheets in all are considered equivalent to one six-sheet strip of single-roll paper. 
6.5.3 The "test load" for the flushing test shall be as given in the following tabulation, depending upon the absorption time of the paper used.

Paper absorption time, double-

strip method, seconds

strips of single-thickness roll

toilet paper.................

0 to $3 \quad 4$ to 6

7
7 to 15

6
5

6.5.4 Method for determining absorption time of paper.-To determine the absorption time of roll toilet paper by the double-strip method, take two two-sheet strips of paper and place them together with perforations in line, and with curvature from roll in same direction in order to insure uniform contact.

6.5.5 These two strips shall then be placed gently on the surface of the water with convex side of paper down. The time in seconds shall be recorded from the moment the paper touches the water until a spot of moisture approximately 1/8 inch in diameter appears on the upper strip. Spots appearing through imperfections in the paper or at edges shall be ignored. (This test can best be made in a lavatory basin or sink where light is usually better than in closet bowl.)

6.5.6 The absorption time of interfold (pack-type) paper shall be determined in the same manner as for roll toilet paper, after first cutting the interfold sheets where folded, then placing the two sheets on the surface of the water.

6.5.7 Procedure for actual testing.-The bowl shall be level, the trap and outlet clear, the bowl filled to weir level, the tank filled to the water line where marked and, in the absence of a mark, to a point 1 inch below top of overflow, and the float valve (ball cock) shall be adjusted to fill tank in not more than 3 minutes.

6.5.8 The given number of six-sheet strips of roll toilet paper as determined by absorption time shall each be crumpled into a loose ball measuring 2 to 3 inches in diameter and dropped all together as a "test load" into the bowl and the bowl flushed immediately. The bowl shall flush similar "test loads" repeatedly without clogging.

6.5.9 If interfold (pack-type) paper is used, six sheets shall be crumpled into a ball in place of each six-sheet strip of roll paper and the test shall be made as outlined above for roll paper.

6.5.10 No paper other than common toilet paper, coming within the absorption time range as mentioned above, shall be used for test.

6.5.11 When water closets to be tested are connected to direct flushing valves, the control stop and valve should first be adjusted for best flushing action. The flow pressure (maintained at the flushingvalve inlet during test) shall not be less than:

10 pounds per square inch for siphon-action closets.

20 pounds per square inch for blow-out closets.

6.6 Method of determining warpage.-The fixture shall be placed on a flat surface so as to ascertain the amount of deviation from the horizontal plane that exists at the edges of the fixture. If a feeler gage of thickness equal to the total allowable warpage will not slide under the fixture without forcing, the fixture satisfactorily comes within the warpage limitations. If the fixture will rock on two opposite high corners, the horizontal plane shall be determined by placing 
one feeler gage, of the total warpage allowed, under one low corner and forcing the fixture down on this gage. If a second feeler gage of the same thickness will not slide under the fixture at any other point, the fixture is not warped out of the horizontal plane by more than the specified tolerance, and satisfactorily comes within the warpage limitations.

\section{MARKING AND LABELING}

7.1 All vitreous china plumbing fixtures shall be plainly and permanently branded for identification with the name or trade-mark of the manufacturer.

7.2 Labels shall be used only on ware that conforms to the requirements for "first quality" as set forth in this commercial standard. It is recommended that manufacturers include the following statement, in conjunction with their name and address, on labels, invoices, guarantees, sales literature, etc.:

The manufacturer declares this vitreous CHINA plumbing fixture to be first quality, and to meet the grading standards and tests of Commercial Standard CS20-49, as developed by the trade under the procedure of the National Bureau of Standards, and issued by the United States Department of Commerce.

7.3 The industry has been embarrassed and the consumer victimized by unscrupulous distributors selling "second" grade fixtures as "first quality" fixtures. In order to prevent the possibility of this unfair practice, all "second" grade ware shall be indelibly marked by the maker with two parallel lines cut through the glaze into the body of the ware at the location (see fig. 25) recommended by the Manu-

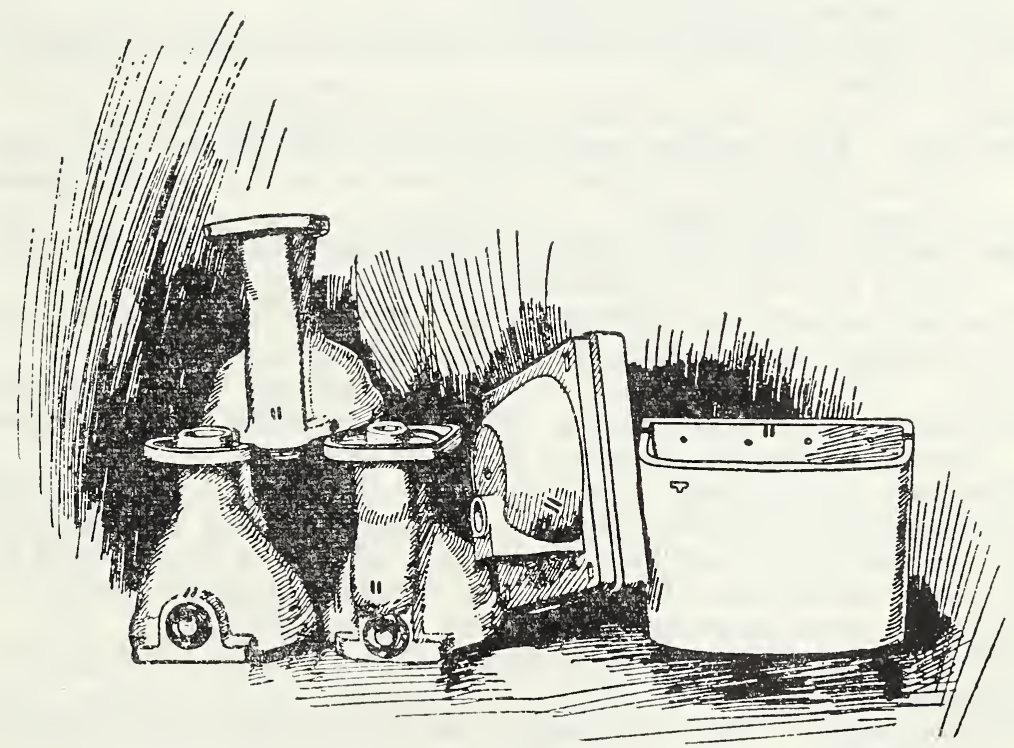

Figure 25. Location and character of marking for seconds. 
facturers' Advisory Committee on Vitreous China Plumbing Fixtures. These cuts shall be filled with a bright red varnish or enamel which is resistant to the action of hot water. No labels shall be placed on "seconds."

7.3.1 All packages containing "seconds" shall be marked with two splashes of red on one end of the package, so as to be visible without tearing down stacks of packages.

\section{NOMENCLATURE AND DEFINITIONS}

8.1 Nomenclature and definitions applicable to vitreous china plumbing fixtures are as follows:

Blister.-A raised portion of the surface $1 / 32(0.031)$ inch and less than $1 / 8$ (0.125) inch in maximum dimension.

Large blister. A A raised portion of the surface $1 / 8(0.125)$ inch to $1 / 4$ $(0.25)$ inch, inclusive, in maximum dimension.

Bubble.-A raised portion of the surface or a sand speck smaller than $1 / 32$ (0.031) inch in maximum dimension.

Craze.-Fine cracks in the glaze.

Discoloration.-A colored spot over $1 / 4$ (0.25) inch in maximum dimension, or a sufficient number of specks or spots to give the effect of a change in color.

Dull or eggshell finish.-Dead or flat finish. Undeveloped glaze. A semiglazed finish with numerous very fine pinholes or slightly matted in appearance. Not glossy.

Dunt.- A hair-line fracture extending through the body, and caused by strains set up in the process of manufacture.

Elongated water-closet bowl.-Water-closet bowl having an elongated top contour as shown in figure 2.

Exposed body.-Unglazed portion $1 / 16$ (0.063) inch or more in maximum dimension.

Finish.-Texture and condition of surface other than color.

Fire check.-Fine shallow crack in the body not covered with glaze. (When sufficiently covered with glaze so as to be easily cleaned, it is not detrimental.)

First quality.-First-class ware in conformity with the grade limitations and other requirements of this standard.

Fittings.-Adjuncts to a fixture subject to selection or option of the purchaser, as, for example, faucets and waste plugs.

Fixture.-The china piece only, without "trimmings" and/or "fittings." Flushing surface.-The surface, visible after installation, which may be wet during the operation of the fixture.

Ledge back.-A flat ledge at the back of a lavatory or sink, not more than 2 inches higher than the rim and extending the full length of the fixture, on which the supply fitting can be mounted and small articles can be placed; or a similar construction with a center panel suitable for mounting a supply fitting.

Pinhole.-A small hole in the glazed surface under 1/16 (0.063) inch in maximum dimension.

Polishing mark.-A spot not larger than $3 / 8$ (0.375) inch in maximum dimension where some minor blemish has been ground off and the surface polished. 
Pottery square:-A square 2 inches on each side. For grading purposes, it may be a 2 -inch square hole cut in a small sheet of any flexible material, such as rubber or paper, for convenience in sliding over irregular surfaces to determine segregation.

Projection.-A raised portion of the surface over $1 / 4(0.25)$ inch in maximum dimension.

Regular (round front) water-closet bowl.-A water-closet bowl having a round front rim. See figure 2.

Roughing-in measurement.-Dimension from finished wall or floor to center of waste or supply opening.

Seconds.-Serviceable ware which grades below "first quality" but which is safe from a health or sanitary point of view.

Segregation.-More than four spots, blisters, or pinholes in any "pottery square."

Shelf back.-A flat elevation at the back of a lavatory, higher than 2 inches above the rim and extending the full length of the fixture, on the top or front of which the supply fitting can be mounted and on which small articles can be placed; or a similar construction with a center panel formed into the shelf suitable for mounting a supply fitting.

Speck. $-\Lambda$ colored portion less than $1 / 32$ (0.031) inch in maximum dimension. Specks less than 1/100 (0.01) inch in maximum dimension, unless in sufficient number to form a discoloration, are not counted.

Spot.-A colored portion of the surface $1 / 32(0.031)$ inch to $1 / 8(0.125)$ inch in maximum dimension.

Large spot. - A colored portion 1/8 (0.125) inch" to $1 / 4$ (0.25) inch, inclusive, in maximum dimension.

Spud.-Threaded brass connection inserted in the vitreous chinaware. Tank.-The term "tank" shall be applied to any vitreous china fixture which contains water to flush another plumbing fixture.

High tank.--Designed to be mounted with bottom more than 2 feet above the floor.

Low tank.-Designed to be mounted with bottom 2 feet or less above the floor.

Trap.-A device so constructed as to prevent the passage of air through a fixture without materially affecting the flow of sewage or waste through it.

Trimmings.-Parts, other than china, regularly supplied with a fixture, as, for example, closet spuds, wall hangers, and tank trim; do not include "fittings."

Visible surface.-The surface which, after installation of the fixture, is readily visible to an observer in normal standing position.

Vitreous china (as applied to plumbing fixtures).-Compounded ceramic materials fired at high temperature to form a vitreous body with exposed surfaces coated with ceramic glaze fused to the body. Vitreous china is impervious to corrosion and discoloration. It does not craze or peel, and the body does not absorb water in excess of $\frac{1}{2}$ of 1 percent of its weight.

Water surface.-The surface of the still water in the water-closet bowl, when filled to the top of the dam. 
Water-closet bowl.-The term "water-closet bowl" is the accepted general term applicable to such fixtures whether singly or part of a "combination."

Water-closet combination.-The term "water-closet combination" applies to a "water-closet bowl" with means for flushing.

Wavy finish.-A defect in the finish having the appearance of numerous runs in the glaze; irregular or mottled.

Well.-A pocket, open at top, formed inside a water-closet bowl at the entrance to the trap.

\section{RECOMMENDED ROUGHING-IN DIMENSION}

9.1 It is recommended that the industry work towards one standard roughing-in dimension for water-closet bowls, and that this dimension be 12 inches.

\section{EFFECTIVE DATE}

10.1 Having been passed through the regular procedure of the Commodity Standards Division, and approved by the acceptors hereinafter listed, this Commercial Standard was issued by the United States Department of Commerce, effective from December 15, 1949.

\section{Edwin W. Ely \\ Chief, Commodity Standards Division}

\section{HISTORY OF PROJECT}

11.1 General conference.-Pursuant to a request from the industry and following several preliminary conferences of interested manufacturers, a public conference was held on September 22, 1926, which resulted in the establishment of Simplified Practice Recommendation R52, Staple Vitreous China Plumbing Fixtures. On recommendation of the standing committee, this was expanded and superseded by a pamphlet entitled "Staple Vitreous China Plumbing Fixtures, Commercial Standard CS20-30."

11.2 - First revision.-The Vitreous China Plumbing Fixtures Association submitted recommended revisions on February 10, 1936, which were subsequently approved by the standing committee, and on April 28, 1936, were circulated to all concerned for written acceptance. As announced to the trade on June 30, 1936, the revised standard was accepted as Commercial Standard CS20-36.

11.3 Second revision.-On January 8, 1942, the Vitreous China Plumbing Fixtures Association submitted recommendations for revision of the standard to include several additional items and tests. With the approval of the standing committee, the revision was circulated to the industry on May 4, 1942, and following receipt of adequate acceptance, the third edition, CS20-42, was announced on June 10, 1942.

11.4 Third revision.-Further changes were recommended on April 19,1946 , by the Vitreous China Plumbing Fixtures Association, in line with developments in the industry. Upon circulation to the industry on December 27, 1946, following approval by the standing committee, 
the revision was accepted in writing by a satisfactory majority, and the fourth edition was announced on June 12, 1947.

11.5 Fourth revision.-On recommendation from the Vitreous China Plumbing Fixtures Association dated March 29, 1948, a revision was prepared to bring the standard into line with current practices, including weights of closet bowls, thickness of ware, and dimensions of tanks, juvenile bowls, bowls for flush-valve operation, and faucet-hole spacing for exposed center-set fittings mounted horizontally. Some rearrangement of general items for greater consistency was made, and several definitions were reworded, including that for vitreous china. The designation "seconds" was substituted for "culls."

After endorsement by the standing committee, the revision was circulated to the industry on June 24, 1949, and upon receipt of signed acceptances representing adequate support by manufacturers, distributors, and users, the fifth edition, CS20-49, was announced on November 15, 1949.

\section{STANDING COMMITTEE}

12.1 The following individuals comprise the membership of the standing committee, which is to review, prior to circulation for acceptance, revisions proposed to keep the standard abreast of progress. Comment concerning the standard and suggestions for revisions may be addressed to any member of the committee or to the Commodity Standards Division, National Bureau of Standards, which acts as secretary for the committee.

\section{D. СоचсH, Chairman}

D. D. Couch, American Radiator \& Standard Sanitary Corp., Pittsburgh 22, Pa. A. G. ZibelL, Kohler Co., Kohler, Wis.

B. B. Pieslak, Abingdon Potteries, Inc., Abingdon, III.

R. H. Zinkil, Crane Co., Chicago 5, Ill.

A. V. Gemmill, Speakman Co., Wilmington 99, Del. John Madden, Jas. B. Clow \& Sons, Chicago 80, Ill.

C. W. Owen, E. G. Schafer \& Co., Washington 2, D. C.

Benjamin Cadbury, Hajoca Corp., Philadelphia 1, Pa.

J. L. Murphy, Chairman, Standardization Committee, National Association of Master Plumbers of the United States, Inc., New York 17, N. Y.

Theodore Irving Coe, Washington 6, D. C. (Representing American Institute of Architects.)

G. R. Studebaker, U. S. Public Health Service, Washington 25, D. C. (Representing American Hospital Association.) 



\section{ACCEPTANCE OF COMMERCIAL STANDARD}

If acceptance has not previously been filed, this sheet properly filled in, signed, and returned will provide for the recording of your organization as an acceptor of this commercial standard.

\section{Date}

Commodity Standards Division,

National Bureau of Standards, Washington 25, D. C.

Gentlemen:

We believe that the Commercial Standard CS20-49 constitutes a useful standard of practice, and we individually plan to utilize it as far as practicable in the
Production $^{1}$
Distribution $^{1}$
Purchase $^{1}$
Testing $^{1}$

of vitreous china plumbing fixtures.

We reserve the right to depart from it as we deem advisable.

We understand, of course, that only those articles which actually comply with the standard in all respects can be identified or labeled as conforming thereto.

Signature of authorized officer

(In ink)

(Kindly typewrite or print the following lines)

Name and title of above officer

Organization

(Fill in exactly as it should be listed)

Street address

City, zone, and State.

1 Underscore which one. Please see that separate acceptances are filed for all subsidiary companies and affiliates which should be listed separately as acceptors. In the case of related interests, trade associations, trade papers, etc., desiring to record their general support, the words "General support" should be added after the signature. 


\section{TO THE ACCEPTOR}

The following statements answer the usual questions arising in connection with the acceptance and its significance:

1. Enforcement.-Commercial standards are commodity specifications voluntarily established by mutual consent of those concerned. They present a common basis of understanding between the producer, distributor, and consumer and should not be confused with any plan of governmental regulation or control. The United States Department of Commerce has no regulatory power in the enforcement of their provisions, but since they represent the will of the interested groups as a whole, their provisions through usage soon became established as trade customs, and are made effective through incorporation into sales contracts by means of labels, invoices and the like.

2. The acceptor's responsibility.- The purpose of commercial standards is to establish for specific commodities, nationally recognized grades or consumer criteria, and the benefits therefrom will be measurable in direct proportion to their general recognition and actual use. Instances will occur when it may be necessary to deviate from the standard and the signing of an acceptance does not preclude such departures; however, such signature indicates an intention to follow the commercial standard where practicable, in the production, distribution, or consumption of the article in question.

3. The Department's responsibility.-The major function performed by the Department of Commerce in the voluntary establishment of commercial standards on a Nation-wide basis is fourfold: first, to act as an unbiased coordinator to bring all interested parties together for the mutually satisfactory adjustment of trade standards; second, to supply such assistance and advice as past experience with similar programs may suggest; third, to canvass and record the extent of acceptance and adherence to the standard on the part of producers, distributors, and users; and fourth, after acceptance, to publish and promulgate the standard for the information and guidance of buyers and sellers of the commodity.

4. Announcement and promulgation.-When the standard has been endorsed by a satisfactory majority of production or consumption in the absence of active, valid opposition, the success of the project is announced. If, however, in the opinion of the standing committee or the Department of Commerce, the support of any standard is inadequate, the right is reserved to withhold promulgation and publication. 


\section{ACCEPTORS}

The organizations listed below have individually accepted this standard for use as far as practicable in the production, distribution, testing, or purchase of staple vitreous china plumbing fixtures. In accepting the standard they reserved the right to depart therefrom as they individually deem advisable. It is expected that articles which actually comply with the requirements of this standard in all respects will be regularly identified or labeled as conforming thereto, and that purchasers will require such specific evidence of conformity.

\section{ASSOCIATIONS}

(General Support)

American Ceramic Society, Columbus, Ohio. A merican Institute of Architects, The, Washington, D. C.

American Society Sanitary Engineering, McKeesport, $\mathrm{Pa}$.

American Specification Institute, Chicago, Ill.

Associated General Contractors of America, Inc., The, Washington, D. C.

Building Officials Conference of America, Inc., Washington, D. C

National Association of Home Builders, Washington, D. C.

National Association of Master Plumbers, New York, N. Y.

Vitreous China Plumbing Fixtures Association, Washington, D. C.

Western Plumbing Officials Association, Los Angeles, Calif.

\section{FIRMS AND OTHER INTERESTS}

AAA Corporation, The, Gadsden, Ala.

Abingdon Potteries, Inc., Abingdon, Ill.

Adams, Franklin O., Tampa, Fla.

Alamo Pottery, Inc., San Antonio, Tex.

Allen, Walter H., Co., Inc., I allas, Tex.

American Plumbers Supply Co., The, Toledo, Ohio.

American Plumbing \& Steam Supply Co., Tacoma, Wash.

American Radiator \& Standard Sanitary Corporation, Pittsburgh, $\mathrm{Pa}$.

Annerican Sanitary Manufacturing Co., Abingdon, Ill. (General support.)

Anderson, F. H., \& Son, Union Springs, Ala.

Andrews, Jones, Biscoe \& Goodell, Boston, Mass.

Appleby Bros. \& Whittaker Co., Harrisburg, Pa.

Bailey, Chas. D., Montgomery, Ala.

Baker Manufacturing Co., Kansas City, Mo.

Barnes Manufacturing Co., Mansfield, Ohio.

Barrett Supply Co., Augusta, Ga.

Barthmaier, Eugene V., Philadelphia, Pa.

Basche-Sage Hardware Co., Baker, Ore.

Baumer, Herbert, Columbus, Ohio.

Bay Hardware, Coos Bay, Ore.

Bayonne Plumbing Supply Co., Bayonne, N. J.

Berger, F. E., R. L. Kelley \& Associates, Champaign, Iil.

Berndt, Hugo W., Milwaukee, Wis.

Bettcher, G. F., Denver, Colo.

Biggs-Kurtz Co., The, Grand Junction, Colo.

Biggs Pump \& Supply, Inc., Lafayette, Ind.

Bilz. Plumbing \& Heating Co., Spring Lake, Mich.

Birdsall, W. A., \& Co., Linden, N'. J.

Bishop, Horatio W., La Mesa, Calif. (General support.)

Blackwell-Wielandy Co., St. Louis, Mo.

Blake-Rounds Supply Co., Portland, Maine.
Boehm, George A., New York, N. Y.

Bond Supply Co., Kalamazoo, Mich.

Bovard, William R., Kansas City, Mo. (General support.)

Brasher Plumbing \& A ppliances, Alexandria, La.

Brazer, Clarence W., New York, N. Y.

Briggs Manufacturing Co., Plumbing Ware Division, Detroit, Mich.

Brodsky, Philip, \& Son, Newark, N. J.

Brooks-Borg, Des Moines, Iowa.

Bruce-Rogers Co., Fort Smith, Ark.

Brust \& Brust, Milwaukee, Wis.

Bucky, Fred W., Jr., Jacksonville, Fla.

Camlet, J. Thomas, Passaic, N. J.

Canfield Supply Co., Kingston, N. Y.

Cannon \& Mullen, Salt Lake City, Utah.

Canton Supply Co., The, Canton, Ohio.

Cantrell Supply Co., Inc., Wichita, Kans.

Careva Co., Inc., The, York, $\mathrm{Pa}$.

Carstens Brothers, Ackley, Iowa.

Case, W. A., \& Son Manufacturing Co., Buffalo, N.Y.

Cedar Rapids Pump \& Supply Co., Cedar Rapids, Inwa.

Cellarius, Charles F., Cincinnati, Ohio.

Central of Georgia Railway Co., Savannah, Ga.

Chadwik, Owen C., Manchester, Mass.

Chicago Pottery Co., Chicago, IIl

Closs, E., Co., Inc., The, Sparta, N. J.

Clow, James B., \& Son, Chicago, Ili.

Cohen, P., \& Son, Brooklyn, N. Y.

Cole, Geo. H., Supply Co., Troy, N. Y.

Cole Supply Co., Ine., Tusealoosa, Ala.

Connor Co., Peoria, Ill.

Conrad \& Cummings, Binghamton, N. Y.

Cook, P. S., Co., Cheyenne, Wyo.

Cook Manufacturing Co., Walnut, Calif.

Coolidge, Shepley, Bulfinch \& A bbott, Boston, Mass.

Coyne \& Delany Co., Brooklyn, N. Y.

Cram \& Ferguson, Boston, Mass.

Crowell \& Lancaster, Bangor, Maine.

Cullen Co., Chicago, Ill.

Daly, M. J., \& Sons, Ine., Waterbury, Conn.

Dalziel Plumbing Supplies, San Francisco, Calif

Davey \& Moen, Mason City, Iowa.

Dericks, John H., Passaic, N. J.

Dearborn Brass Co., Cedar Rapids, Iowa. (General support.)

Detroit Sanitary Manufacturing Co., Division of Detroit Brass \& Malleable Works, Detroit, Mich. (General support.)

Detroit, City of, Department of Buildings and Safety Engineering, Detroit, Mich.

Dietel, G. J., Buffalo, N. Y.

Dobbins, W. C., Trenton, N. J

Dornack, Herman, Rochester, Minn.

Douglas, John, Co., The, Cincinnati, Ohio.

Dubuque, R. A., Supply Co., St. Louis, Mo.

Dugan, T. M., McKeesport, Pa.

Du-Kane Supply Co., Pittsburgh, Pa.

Duluth Plumbing Supplies Co., Duluth, Minn. 
Duner Co., Chicago, $\mathrm{Il}$.

Dunning, R. B., \& Co., Bangor, Maine.

Elizabeth Plumbing \& Heating Supply Co., Eliza. beth, N. J.

Eljer Co., Ford City, Pa.

Fall River Steam \& Gas Pipe Co., Fall River, Mass. Federal Huber Co., Chicago, $n 1$.

Field \& Shorb Co., The, Decatur, Ill.

Flannagan, Eric G., Henderson, N. C.

Florida A utomobile \& Gas Engine Co., Tampa, Fla.

Florida, University of, Department of Architecture,

Board of Control, Gainesville, Fla.

Fords Porcelain Works, Perth Amboy, N. J

Georgia Sanitary Pottery, Inc., Atlanta, Ga.

Gibson Schlemmer Co., The, Cincinnati, Ohio.

Glauber, Inc., New York, N. Y.

Glenn, R. S, Eastland, Tex.

Graf \& Dellwardt, Inc., Buffalo, N. Y.

Green, Raymond C., \& Co., Jenkintown, Pa.

Hajoca Corporation, Philadelphia, $\mathrm{Pa}$.

Hallsted, H. E. Hay Springs, Nebr.

Hansen Plumbing Co., Dallas, Tex.

Hardison, Robert E., Kiowa, Kans.

Hardware \& Supply Co., The, Akron, Ohio.

Harley, Ellington \& Day, Ine., Detroit, Mich.

Harper \& Reynolds Corporation, Los Angeles, Calif.

Harris Pump \& Supply Co., Pittsburgh, Pa.

Hartford Plumbing Supply, Inc., Hartford, Conn.

Haxby, Bissell \& Belair, Minneapolis, Minn.

Helfensteller, Hirsch \& Watson, St. Louis, Mo.

Herrmann, F. W., Co., Inc., Guttenberg, N. J.

Hess, Charles, Co., New York, N. Y

Hoe Supply Co., Christopher, Ill.

Hoggson Brothers, Inc., New York, N. Y.

Hoke, Karl B., Toledo, Ohio.

Hope, Frank L.. San Diego, Calif.

Hornberger, L. F., Dwight, Ill.

Hospital Bureau of Standards \& Supplies, Inc., New York, N. Y.

Hubbard, S. B., Co., The, Jacksonville, Fla.

Hubert, Karl, Connersville, Ind.

Hughes Heating \& Plumbing Co., The, Minneapolis, Minn.

Hughes Supply Co, The, Mansfield, Ohio.

Hunter, Alfred J, \& Co, Muskegon, Mich.

Hunting Co., The, Rochester, N. Y.

Hutchings, E. T., Louisville, Ky.

Ideal Manufacturing \& Supply Co., Oskaloosa, Iowa.

Industrial Supply Co. Terre Haute, Ind.

Interstate Hardware Co., Inc., Bristol, Tenn.

Jacobson, A. D., Plumbing \& Heating Co., Ine., Kansas City, Ḿo.

James, W. T., Hardware \& Plumbing Co., Bisbee, Ariz.

Jardine Plumbing Co., The, Chillicothe, Ohio. Jefferson Supply Co., Pine Blufi, Ark.

Johns Hopkins Hospital, The, Baltimore, Md.

Johnson Hardware Co, Clarksburg, W. Va.

Jones, John Paul, \& Leonard Bindon, Seattle, Wash. (General support.)

Jones-Kay Co., Pendleton, Oreg.

Kahn, Albert, Associated Architects \& Engineers, Inc, Detroit, Mich.

Kalispell Mercantile Co, Kalispell, Mont.

Kansas State College, Manhattan, Kans.

Keich \& O'Brien, Warren, Ohio.

Keiser-Van Leer Associates, Bloomington, Ill.

Kennedy Co., The, Cleveland, Ohio.

Kilgore Ceramics Corporation, Kilgore, Tex.

Kinsey, H. P., Co., Easton, Pa.

Klebart Plumbing Supply House, Webster, Mass.

Klink, N. S., \& Co., Phoenix, Ariz.

Knapp Supply Co., The, Muncie, Ind.

Kohler Co., Kohler, Wis.

Koller Brothers Co., The, Cleveland, Ohio.

Kowalsky, Edw. J., Oxford, Mich.

Kyle, Herbert S., Charleston, W. Va.

La Crosse Plumbing Supply Co., La Crosse, Wis.

Lansing Supply Co., Lansing, Mich.

Latenser, John, \& Sons, Omaha, Nebr.

Law, Law, Potter \& Nystrom, Madison, Wis.

Leavy, Harry H., Stanhope, N. J.

Lee, George G., Co., Inc., Norfolk, Va.

Lee Hardware Co., 'The, Salina, Kans.

Lee \& Hewitt, Paterson, N. J.

Lehigh Plumbing \& Heating Co., Allentown, $\mathrm{Pa}$
Levine, Samuel, New York, N. Y.

Levy, Will, St. Louis, Mo.

Loeb, Laurence M. White Plains, N. Y.

Long Supply Co., Chicago, Ill.

Lorenz Co., Klamath Falls, Oreg.

Malone Plumbing Supply Co., Pittsburgh, Pa.

Mann \& Co., Hutchinson, Kans.

Mansfield Sanitary Pottery, Inc., Perrysville, Ohio.

Marr, Charles J., New Philadelphia, Ohio.

Martin, Edgar, Chicago. Ill.

Massena \& duPont, Wilmington, Del.

May Supply Co., Anderson, Ind.

McAuliffe \& Burke Co., Boston, Mass.

McClung, C. M., \& Co., Inc., Knoxville, Tenn.

MeGowin Lyons Hardware \& Supply Co., Mobile, Ala.

McNeill, O. H., Herrin, Ill.

Mechanical Construction Corporation, Hibbing, Minn.

Meyer, F. \& J., New York, N. Y.

Michigan Supply Co., Lansing, Mich.

Michigan, University of, University Hospital, Ann Arbor, Mich.

Midland Plumbing Supply Co., Inc., East St. Louis, Ill.

Milano, M. Joseph, North Quincy, Mass.

Miller \& Vrydagh, Terre Haute, Ind.

Mineola Plumbing Supply Co., Inc., Mineola, N. Y.

Molther, F. R., Ancon, Canal Zone.

Monahan, Meikle \& Johnson, Pawtucket, R. I. (General support.)

Monroe Co., Boston, Mass.

Mooser, William, San Francisco, Calif.

Moran, Clifford, Plumbing \& Heating Service,

Highland Park, Ill.

Morlev Brothers, Saginaw, Mich.

Morrison Supply Co., Fort Worth, Tex.

Mott Bros. Co., Rockford, Ill.

Moulton's Vitreous Products, Inglewood, Calif.

Muhlenberg Bros., Reading, Pa.

Muller, Fritz, New York, N. Y. (General support.)

Muntz, Henry, \& Sons Co., Elgin, Ill.

Murphy Supply Co., Creen Bay, Wis.

National Plumbing Pottery, Columbus, Ohio.

Nelson, N. O., Co., St. Luuis, Mo.

Nelson Supply Co., Hutchinson, Kans.

New Jersey Engineering \& Supply Co., Passaic, N. J.

New York Plumbers Specialties Co., Inc., New

York, N. Y.

Oakland Public Schools, Oakland, Calif.

O'Donnell, Val. I., Co., Worcester', Mass.

Officer, Gwynn, Iafayette, Calif.

Orange Memorial Hospital, Orange, N. J.

O'Rourke, W. R., Plumbing \& Heating Co., Walla Walla, Wash.

Osterfeld, H. J., Co., The, Dayton, Ohio.

Otto, Henry W., Milwaukee, Wis.

Park \& McKay Co., Detroit, Mich.

Patterson, W. S., Co., Appleton, Wis.

Pederson \& Hueber, Syracuse, N. Y.

Peerless-Oklahoma Co., Oklahoma City, Okla.

Pehrson, G. A., \& Associates, Spokane, Wash.

Pepper, Geo. W., Jr., Philadelphia, Pa.

Phelps, Frederick A., Associated Architects and Engineers, Newark, N. J.

Piers, Eber F., Ogden, Utah.

Pitt, Walter A., \& Co., Bloomfield, N. J.

Plimpton \& Hills Corporation, The, Hartford, Conn.

Plumbers' Supply Co., New Bedford, Mass.

Poekert, R. A., Pittsburgh, Pa.

Post, Hugo R., Chilton, Wis.

Providence Pipe \& Sprinkler Co., Providence, R. I.

Raffel Supply Co., Chicago, Ill.

Rains, Raymond, Louisville, Ky.

Rayl Co., The, Detroit, Mich.

Reading Foundry \& Supply Co., Reading, Pa.

Redmond, Geo., Co., The, Cleveland, Ohio.

Reger, Frank A., \& Śons, Baltimore, Md.

Riber, George L., Detroit, Mich.

Riggs, Lutah Maria, Santa Barbara, Calif.

Richmond Radiator Co., New York, N. Y

Ritchie, James H., \& Associates, Boston, Mass.

Roberts-Hamilton Co., Minneapolis, Minn.

Robertshaw, Milton M., \& Son, West Orange, N. J.

Rochester, City of, Board of Education, Rochester,

N. Y. 
Rogers Ebert Co., Inc., Orange, N. J.

Roosevelt, W. A., Co., La Crosse, Wis.

Royal Brass Manufacturing Co., The, Cleveland, Ohio.

Rubly, William, \& Sons, Indianapolis, Ind.

Russell, Crowell, Mullgardt \& Schwarz, St. Louis, Mo.

Sanitary Plumbing Co., Redlands, Calif.

Schafer, E. G., \& Co., Washington, D. C.

Schmidt Plumbing \& Heating, Anaconda, Mont.

Seaford Plumbing Supply Co., Seaford, Del.

Sears, Roebuck \& Co., Chicago, Ill.

Seashore Supply Co., Atlantic City, N. J.

Seattle Plumbing Supply Co., Seattle, Wash.

Shepard Co., Inc., The, White River Junction, Vt.

Shivers, W. M., Plumbing Supply Co., Houston, Tex.

Shoemaker, O. I., Sebring, Fla.

Sirrine, J. E., Co., Greenville, S. C.

Sleeper, Harold R. New York, N. Y.

Sloan Valve Co., Chicago, Ill.

Smith, Hinchman \& Grylls, Inc., Detroit, Mich.

Smith Parish, Inc., Portville, N. Y.

Somerville, Thos., Co., Washington, D. C.

South Plumbing Supply Co., Inc., Jamaica, N. Y.

Southside, Plumbing \& Heating Maintenance, Freeport, N. Y.

Spangler Plumbing Co., Birmingham, Ala.

Speakman Co., Wilmington, Del.

Staub \& Rather, Houston, Tex.

Stoetzel, Ralph, Chicago, Ill.

Streeter, Daniel D., Brooklyn, N. Y.

Sweet's Catalog Service, New York, N. Y. (General support.)

Tallman Co., St. Louis, Mo.

Taub Plumbing Supply Co., Inc., Newark, N J.

Taylor, Ellis Wing, Los Angeles, Calif.

Taylor Plumbing Co., Grand Rapids, Minn.

Temple, Arthur, Davenport, Iowa.

Tennessce Mill \& Mine Supply Co., Knoxville, Tenn.

Texas Technological College, Dcpartment of Architecture, Lubbock, Tex. (General support.)

Thill Supply Co., Inc., Brooklyn, N. Y.

Thompson-Durkee Co., Allston, Mass.

Thorne, Henry Calder, Ithaca, N. Y.

Thornley Supply Co., Pawtucket, R. I.

Treaty Co., The, Greenville, Ohio.

Trenton Potteries Co., The, Trenton, N. J.

Trimble \& Lutz Supply Co., Wheeling, W. Va.

Trumbull Plumbing Supply Co., Inc., Warren, Ohio.

Turner \& Van Scoy Co., Inc., Wilkes-Barre, Pa.

Tyson Bros., Mesa, Ariz.
United States Testing Co, Inc, Hoboken, N. J.

Universal-Rundle Corporation, New Castle, $\mathrm{Pa}$

Valley Supply Corporation, Neenah, Wis.

Van Denberg Supply Co., Rockford, Ill.

Virginia, University of, Department of Architecture, Blacksburg, Va.

Voell Co., Washington, D. C.

Vogel, Joseph A., Co., Wilmington, Del

Walker Supply Ćo., Trenton, N. J.

Warburton's, Madera, Calif.

Wankesha Memorial Hospital, Waukesha, W is

Webb, F. W., Manufacturing Co., Boston, Mass.

Wcber, C. L., \& Co., Inc., Philadelphia, Pa.

Weeks, Ralph E., Co., Scranton, Pa.

Weekes, John, \& Son Co, Watertown, N. Y

Weil Bros., Inc., New York, N. Y.

Weiss Plumbing Supply Co., Brooklyn, N. Y.

Welch, Carroll E., Huntington, N. Y.

Welker Supply Co., The, Cleveland, Ohio.

West, Albert E., Boston, Mass.

Western Electric Co., Inc., Manufacturing Division, New York, N. Y.

Western Metal Supply Co., San Diego, Calif.

Western Supply Co., Lincoln, Nebr.

Westwater Supply Co., Columbus, Ohio

White \& Shauger, Inc., Paterson, N. J.

Whitney \& Ford Co., Chicago, Ill.

Whittle Plumbing Co., Palmetto, Fla.

Wigman Co., Sioux City, Iowa.

Willatsen, Andrew, Seattle, Wash.

Wisconsin River Supply Co., Wausau, Wis.

Withey, Henry F., Sherman Oaks, Calif.

Wolf, Louis G., Henderson, $\mathrm{Ky}$.

Wolverine Brass Works, Grand Rapids, Mich.

Wood, Edward J., \& Son, Clarksburg, W. Va.

Woolcock Plumbing \& Heating Co., Niagara Falls, N. Y.

Worthen, A. B., Co., Methuen, Mass.

Worthington, George, Co., The, Cleveland, Ohio.

Wright \& Wright, Detroit, Mich. (General support.)

Zimmerman, A. C., Los Ángeles, Calif.

\section{U. S. GOVERNMENT}

Agriculture, United States Department of, Division of Purchase, Sales and Traffic, Washington, D. C. Army, Department of the, Washington, D. C.

Interior, Department of, Bureau of Indian Affairs, Washington, D. C.

Justice Department, Bureau of Prisons, Washington D. C.

United States Public Health Service, Washington. D. C.

Vetcrans Administration, Washington, D. C. 


\section{COMMERCIAL STANDARDS}

CS No.

Item

0-40. Commercial standards and their value to business (third cdition).

1-42. Clinical thermometers (third edition).

2-30. Mopsticks.

3-40. Stoddard solvent (third edition)

4-29. Staple porcelain (all-clay) plumbing fixtures.

5-46. Pipe nipples; brass, copper, steel and wroughtiron (second edition).

6-31. Wrought-iron pipe nipples (second edition). Superseded by CS5-46.

7-29. Standard weight malleable iron or stecl screwed unions.

8-41. Gage blanks (third edition)

9-33. Builders' template hardware (second edition).

10-29. Brass pipe nipples. Supcrseded by CS5-46.

11-41. Moisture regains of cotton yarns (second edition).

12-48. Fuel oils (sixth edition)

13-44. Dress patterns (fourth edition)

14-43. Boys' button-on waists, shirts, junior and sport shirts (made from woven fabrics) (third edition)

15-46. Men's pajama sizes (made from woven fabrics) (third edition)

16-29. Wall paper.

17-47. Diamond core drill fittings (fourth edition).

18-29. Hickory golf shafts.

19-32. Foundry patterns of wood (second edition).

20-49. Vitreous china plumbing fixtures (fifth edition).

21-39. Interchangeable ground-glass joints, stopcocks, and stoppers (fourth edition)

22-40. Builders' hardware (nontcmplate) (second edition)

23-30. Feldspar.

24-43. Screw threads and tap-drill sizes.

25-30. Special screw threads, Superseded by CS$24-43$.

26-30. A romatic red cedar closet lining.

27-36. Mirrors (second edition)

28-46. Cotton fabric tents, tarpaulins and covers (second edition)

29-31. Staple seats for water-closet bowls.

30-31. Colors for sanitary ware. (Withdrawn as commercial standard March 15, 1948.)

31-38. Wood shingles (fourth edition).

$32-31$. Cotton cloth for rubber and pyroxylin coating.

33-43. Knit underwear (exclusive of rayon) (seconi edition)

34-31. Bag, case, and strap leather.

35-47. Hardwood plywood (third edition).

36-33. Fourdrinier wire cloth (second edition).

37-31. Steel bone plates and screws.

38-32. Hospital rubber sheeting.

39-37. Wool and part wool blankets (second edition) (Withdrawn as commercial standard, July 14, 1941.)

40-32. Surgeons' rubber gloves.

41-32. Surgeons' latex gloves.

42-43. Structural fiber insulating board (third edition).

43-32. Grading of sulphonated oils.

44-32. Apple wraps.

45-48. Douglas fir plywood (eighth edition).

46-49. Hosiery lengths and sizes (fourth edition).

47-34. Marking of gold-filled and rolled-gold-plate articles other than watchcases.

48-40. Domestic burners for Pennsylvania anthracite (underfeed type) (second edition).

49-34. Chip board, laminated chip board, and miscellaneous boards for bookbinding purposes.

50-34. Binders board for bookbinding and other purposes.
Item

CS No.

51-35. Marking articles made of silver in combination with gold.

52-35. Mohair pile fabrics (100-percent mohair plain velvet, 100-percent mohair plain frieze, and 50 -percent mohair plain frieze).

33-35. Colors and finishes for cast stone.

54-35. Mattresses for hospitals.

55-35. Mattresses for institutions.

56-49. Oak flooring (third edition).

57-40. Book cloths, buckrams, and impregnated fabrics for bookbinding purposes cxcept library bindings (second edition).

58-36. Woven clastic fabrics for use in overalls (overall elastic webbing)

59-44. Textiles-testing and reporting (fourth edition).

60-48. Hardwood dimension lumber (second edition).

61-37. Wood-slat venetian blinds

32-38. Colors for kitchen accessories.

63-38. Colors for bathroom accessories.

64-37. Walnut veneers.

65-43. Methods of analysis and of reporting fiber composition of textile products (second edition).

66-38. Marking of articles made wholly or in part of platinum.

67-38. Marking articles made of karat gold.

68-38. Liquid hypochlorite disinfectant, deodorant, and germicide.

69-38. Pine oil disinfectant.

70-41. Phenolic disinfectant (emulsifying type) (second edition) (published with CS71-41,

71-41. Phenolic disinfectant (soluble type) (sccond edition) (published with CS70-41).

72-38. Household insecticide (liquid spray typc).

73-48. Old growth Douglas fir, Sitka spruce, and Western hemlock standard stock doors (fourth edition).

74-39. Solid hardwood wall paneling

75-42. Automatic mechanical draft oil burners designed for domestic installations (second edition).

76-39. Hardwood interior trim and molding.

77-48. Enameled cast-iron plumbing fixtures (second edition).

78-40. Ground-and-polished lenses for sun glasses (second edition) (published with CS79-40).

79-40. Blown, drawn, and dropped lenses for sun glasses (second edition) (published with CS78-40)

80-41. Electric direction signal systems other than semaphore type for commercial and other vehicles subject to special motor vehicle laws (after market).

81-41. Adverse-weather lamps for vehicles (after market).

82-41. Inner-controlled spotlamps for vehicles (after market).

83-41. Clearance, marker, and identification lamps for vehicles (after market).

84-41. Electric tail lamps for vehicles (after market)

85-41. Electric license-plate lamps for vehicles (after market)

86-41. Electric stop lamps for vehicles (after market).

87-41. Red electric warning lanterns.

88-41. Liquid burning flares.

89-40. Hardwood stair treads and risers.

90-49. Power cranes and shovels.

91-41. Factory-fitted Douglas fir entrance doors.

92-41. Cedar, cypress and redwood tank stock lumber. 
CS No.

Item

93-41. Portable electric drills (exclusive of high frequency).

94-41. Calking lead.

95-41. Lead pipe.

96-41. Lead traps and bends.

97-42. Electric supplementary driving and passing lamps for vehicles (after market)

98-42. Artists' oil paints.

99-42. Gas floor furnaces-gravity circulating type.

100-47. Porcelain-enameled steel utensils (third edition).

101-43. Flue-connected oil-burning space heaters equipped with vaporizing pot-type burners.

102- . (Reserved for Diesel and fuel-oil engines).

103-48. Rayon jacquard velour (with or without other decorative yarn) (second edition).

104-49. Warm-air furnaces equipped with vaporizing type oil burners (third edition).

105-48. Mineral wool insulation-for low temperatures (second edition).

106-44. Boys' pajama sizes (woven fabries) (second edition).

107-45. Commercial electric-refrigeration condensing units (second edition). (Withdrawn as commercial standard September 4, 1947.)

108-43. Treading automobile and truck tires.

109-44. Solid-fuel-burning forced-air furnaces.

110-43. Tire repairs-vulcanized (passenger, truck, and bus tires)

111-43. Earthenware (vitreous-glazed) plumbing fixtures.

112-43. Homogeneous fiber wallboard.

113-44. Oil-burning floor furnaces equipped with vaporizing pot-type burners.

114-43. Hospital sheeting for mattress protection.

115-44. Porcelain-enameled tanks for domestic use.

116-44. Bituminized-fiber drain and scwer pipe.

117-49. Mineral wool insulation for heated industrial equipment (second edition).

118-44. Marking of jewelry and novelties of silver.

(E)110-45. 1 Dial indicators (for lincar measurements).

(E)120-48. Standard stock ponderosa pine doors (third edition)

121-45. Women's slip sizes (woven fabries).

122-45. Western hemlock plywood.

123-49. Grading of diamond powder (second edition).

(E) 124-45. Master disks.

125-47. Prefabricated homes (second edition).

126-45. Tank mounted air compressors.

127-45. Self - c on ta in ed mechanically refrigerated drinking water coolers.
CS No.

Item

128-45. Men's sport shirt sizes-woven fabries (other than those marked with regular neckband sizes).

129-47. Materials for safety wearing apparel (second edition)

130-46. Color materials for art education in schools.

131-46. Industrial mineral wool products, all types-testing and reporting.

132-46. Hardware cloth.

133-46. Woven wire netting.

134-46. Cast-aluminum cooking utensils (metal composition)

135-46. Men's shirt sizes (exclusive of work shirts).

136-46. Blankets for hospitals (wool, and wool and cotton).

137-46. Size mcasurements for men's and boys' shorts (woven fabries).

138-47. Insect wire screening.

139-47. Work gloves.

140-47. Testing and rating convectors.

141-47. Sine bars, blocks, plates, and fixtures.

142-47. Automotive lifts.

143-47. Standard strength and extra strength perforated clay pipe.

144-47. Formed metal porcelain enameled sanitary ware.

145-47. Testing and rating hand-fired hot-watersupply boilers.

146-47. Gowns for hospital patients.

147-47. Colors for molded urea plastics.

148-48. Men's circular flat and rib knit rayon underwear.

149-48. Utility type house dress sizes.

150-48. Hot rolled rail steel bars (produced from Tee-section rails).

151-48. Body measurements for the sizing of apparel for infants, babies, toddlers, and children (for the knit underwear industry).

152-48. Copper naphthenate wood-preservative.

153-48. Body measurements for the sizing of apparel for girls (for the knit underwear industry).

154- . (Reserved for wire rope)

155-49. Body measurements for the sizing of apparel for boys (for the knit underwear industry).

156-49. Colors for polystyrene plastics.

157-49. Ponderosa pine and sugar pine plywood.

158-49. Model forms for girls' apparel.

159-49. Sun-glass lenses made of ground and polished plate glass, thereafter thermally curved.

NotE.-Where “(E)" precedes the CS number, it indicates an emergency commercial standard, drafted under war conditions with a view toward early revision.

NотісE.-Those interested in commercial standards with a view toward accepting them as a basis of everyday practice may secure copies of the above standards, while the supply lasts, by addressing the Commodity Standards Division, National Bureau of Standards, Washington 25, D. C. 
